\title{
Bacterial Cellulose as a Versatile Platform for Research and Development of Biomedical Materials
}

\author{
Selestina Gorgieva ${ }^{1,2}$ (B) \\ 1 Institute of Engineering Materials and Design, Faculty of Mechanical Engineering, University of Maribor, \\ Smetanova ul. 17, SI-2000 Maribor, Slovenia; selestina.gorgieva@um.si; Tel.: +386-2-220-7924; \\ Fax: +386-2-220-7990 \\ 2 Institute of Automation, Faculty of Electrical Engineering and Computer Science, University of Maribor, \\ Koroška cesta 46, SI-2000 Maribor, Slovenia
}

Received: 8 May 2020; Accepted: 20 May 2020; Published: 22 May 2020

check for updates

\begin{abstract}
The unique pool of features found in intracellular and extracellular bacterial biopolymers attracts a lot of research, with bacterial cellulose (BC) being one of the most versatile and common. $\mathrm{BC}$ is an exopolysaccharide consisting solely of cellulose, and the variation in the production process can vary its shape or even its composition when compounding is applied in situ. Together with ex situ modification pathways, including specialised polymers, particles or exclusively functional groups, BC provides a robust platform that yields complex multifunctional compounds that go far beyond ultra-high purity, intrinsic hydrophilicity, mechanical strength and biocompatibility to introduce bioactive, $(\mathrm{pH}$, thermal, electro) responsive, conductive and 'smart' properties. This review summarises the research outcomes in BC-medical applications, focusing mainly on data from the past decade (i.e., 2010-2020), with special emphasis on BC nanocomposites as materials and devices applicable in medicine. The high purity and unique structural/mechanical features, in addition to its capacity to closely adhere to irregular skin surfaces, skin tolerance, and demonstrated efficacy in wound healing, all stand as valuable attributes advantageous in topical drug delivery. Numerous studies prove BC compatibility with various human cells, with modifications even improving cell affinity and viability. Even $\mathrm{BC}$ represents a physical barrier that can reduce the penetration of bacteria into the tissue, but in its native form does not exhibit antimicrobial properties, therefore carious modifications have been made or specific compounds added to confer antimicrobial or anti-inflammatory properties. Progress in the use of BC-compounds as wound dressings, vascular grafts, and scaffolds for the treatment of cartilage, bone and osteochondral defects, the role as a basement membrane in blood-brain barrier models and many more are discussed to particular extent, emphasising the need for $\mathrm{BC}$ compounding to meet specific requirements.
\end{abstract}

Keywords: bacterial cellulose; biocompatibility; biomedical application; wound dressings; scaffolds; drug delivery; antimicrobial; medical device

\section{Introduction}

Biopolymers are produced by living organisms, namely the prokaryotes and eukaryotes, as extraor intracellular compounds, synthesised by means of processive enzymes. Latter 'joins' the amino acids, sugars, sugar acids, hydroxy fatty acids or inorganic phosphates utilising glucosidic, peptide, ester or anhydride bonds to form molecules with higher molecular weight, such as polysaccharides, polyamides, polyesters, and polyphosphates. Ref. [1] Acting as a prime cell factories, different bacteria utilise the carbon and nitrogen sources, transforming them into complex compounds from group of polysaccharides, polyamides, polyesters, polyphosphates, extracellular DNA and proteins, etc. 
The unique combination of properties found in intracellular and extracellular bacterial biopolymers attracts a wide range of research, with bacterial cellulose (BC) being one of the most versatile and common. $\mathrm{BC}$ is a homopolysaccharide consisting of cellulose $\left(\mathrm{C}_{6} \mathrm{H}_{10} \mathrm{O}_{5}\right) \mathrm{n}$, in the form of a linear monosaccharide chain $\beta$-D-glucose linked by a $\beta(1 \rightarrow 4)$ bond, the repeating unit consisting of two glucose units, i.e., cellobiose (Figure 1).
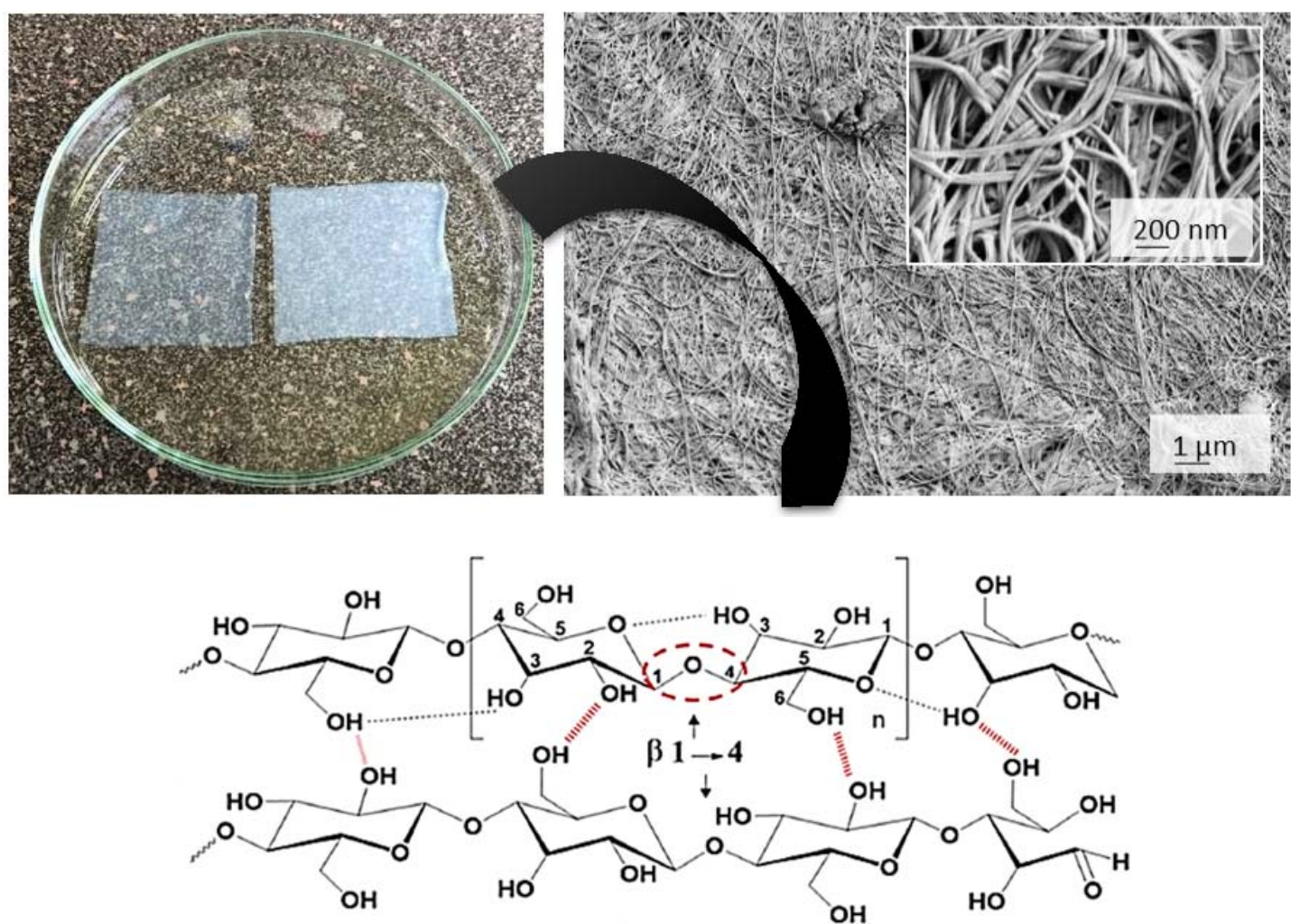

Figure 1. Macro-, micro- and molecular structure of bacterial cellulose (BC) membrane. Molecular structure image adapted from [2].

$\mathrm{BC}$ is produced as an exopolysaccharide from various Gram-, non-pathogenic bacterial strains, such as Achromobacter, Alcaligenes, Aerobacter, Agrobacterium, Azotobacter, Pseudomonas, Rhizobium, Sarcina, Dickeya and Rhodobacter, which have been reported to extracellularly produce BC, nevertheless the genus Komagataeibacter (formerly Acetobacter xylinum) is the most commonly reported strain. Ref. [3-6] This bacterium produces BC by two coupled processes: First presenting the polymerization of glucose residues, joining within $\beta-1,4$ linear glycan chains and extracellular secretion, and second, the crystallization phase where chains fuse alongside and formed microfibrils. The second phase follows the formation of layers of glucan chains by van der Waals forces and the assembling of the layers into ribbons, made of up to 100 microfibrils. Ref. [7] A certain number of monofilaments aggregated into fibrous fibres (like ribbons) with a width of 20-60 nm, which solidify on the culturing medium surface of a liquid medium to form a three-dimensional, gelatinous, highly entangled network.

Various wastes and by-products have been studied as carbon sources: fruits, the biodiesel by-product glycerol, date syrup, commercial sucrose, stillage from rice mine distillation, hydrolysates from wheat straw and cotton fabric, grape bagasse, saccharified food waste, flour from bread and confectionery waste, waste from the sunflower-based biodiesel industry, etc. BC share same molecular formula as plant celluloses, yet is free of lignin, hemicelluloses and pectin found in its plant- relatives; it also possess distinguished features, such as ultra-high (up to 90\% crystallinity), polymerization degree 1000 units, large surface area derive from $<100$ nm-thick fibres, remarkable mechanical properties in term of flexibility and tensile strength, high water holding capacity (two logs higher than its dry weigh), etc. Ref. [8] As a high-purity biological nonwoven, the BC gained interest in 
medicine for 30 years, where its use range from simple wound bandaging biotextile, up to complex skin replacement, membrane use in dentistry, hemostatic material, artificial membrane for engineering of blood vessels, covering in nerve surgery, dura mater prosthesis, arterial stent coating, scaffolds for bone and cartilage regeneration and even more [8].

The $\mathrm{BC}$ conforms fully to green chemistry principles, which fits well with the objectives of the circular economy, including the minimization and reuse of waste as a feedstock, and pointing out on the importance of engaging more research efforts for BC production and adaptation towards high-value markets such as the medical market, Ref. [9]. Together with the unique combination of properties that fit well with the requirements of tailor-made medical products, these are the main reasons for the interest in $\mathrm{BC}$ that has grown rapidly over the past decade, as shown by the trend line of publications for the period 2010-2020 (Figure 2).

The aim of the present review is therefore to emphasise the role of $\mathrm{BC}$ not as a single material but as a large platform for material development in the biomedical field, focusing on published data from the last decade (2010-2020).

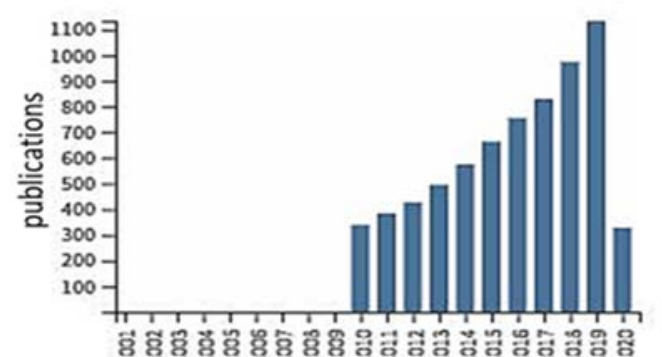

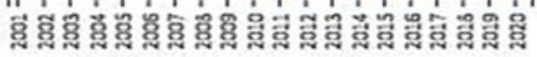

a)
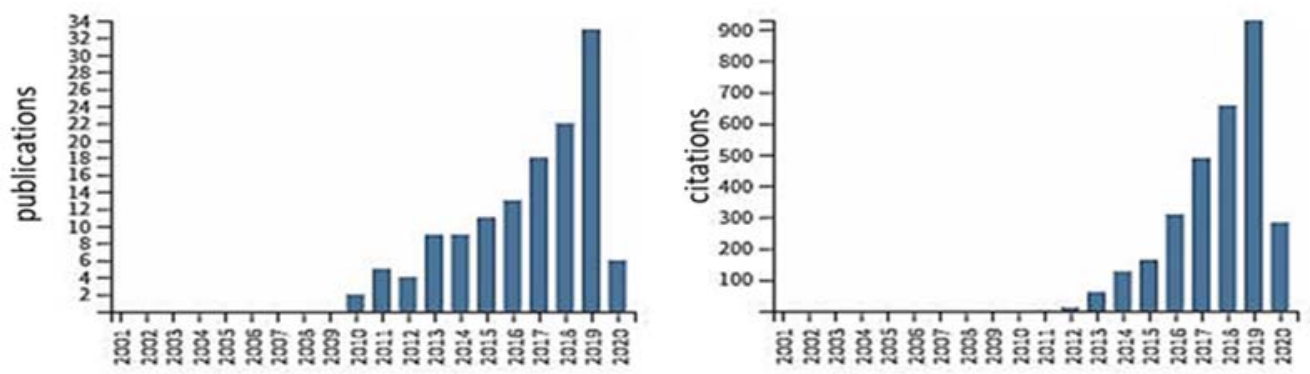

b)

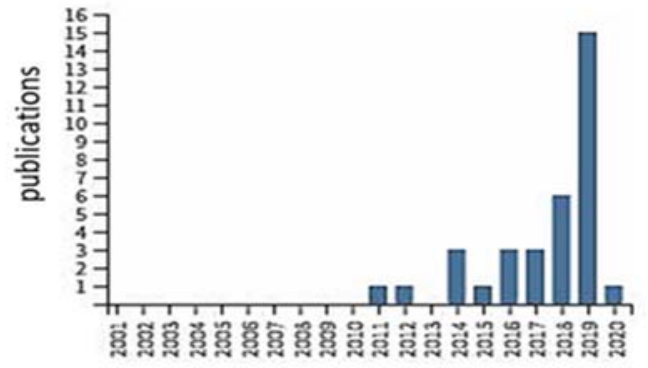

c)

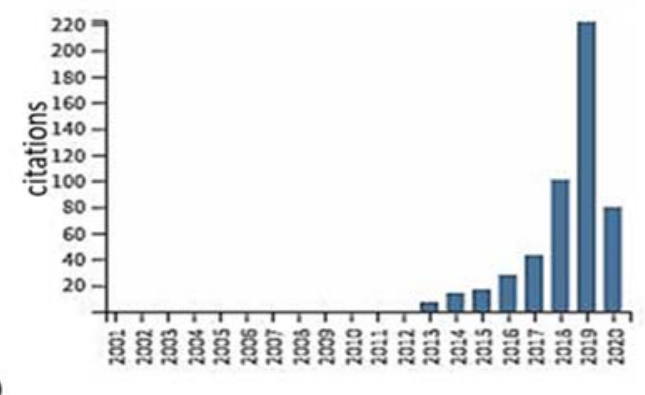

Figure 2. Trend of annual publications considering BC for 2010-2020 period. Search engine is Web of Science Core Collection and search terms (a), 'bacterial cellulose' (b), 'bacterial cellulose' AND 'medicine', (c) and 'bacterial cellulose' AND ‘medicine' AND 'review'.

\section{BC Modifications and Compounding}

Structural compactness derive from small size of voids (pores) within BC network, degradation resistance (particularly in vivo) and lack of bioactivity are among the major limitations of native $\mathrm{BC}$ when more specific medical applications are considered. In the latter case, native BC is not sufficient as 
a stand-alone material, for which various physic-chemical, mechanical and biosynthetic modification routes have been proposed, using (multi) functional polymers, solvents, and particles that introduced new or elicit the superior properties over their plain BC counterparts. Detailed reviews describing the most efficient modification routes have recently been published by Gorgieva and Trček [8].

The microstructure, morphology and composition of BC product can be modified at the stage of biosynthesis, known as in situ modification. The attractive forces and interactions between the BC polysaccharide chains, i.e., Van der Waals forces and intermolecular hydrogen bonds, can be adjusted by simple addition of specific agents or particles. The latter affects the arrangement and composition of the amorphous and crystalline regions, determining the crystallinity profile and microstructure of resulting $\mathrm{BC}$ product. Lv et al. [10] fabricate two-layer nanofibrous material using the potato starch (PS) granules in order to interrupt and disassemble dense nanofiber net, formed at liquid-air interface during static culturing. This creates larger voids within the fibre network (Figure 3). Resulting membrane was seeded with the muscle cells on top, creating a biomaterial candidate for the reconstruction of hollow organs, including blood vessels, intestine, bladder and oesophagus.

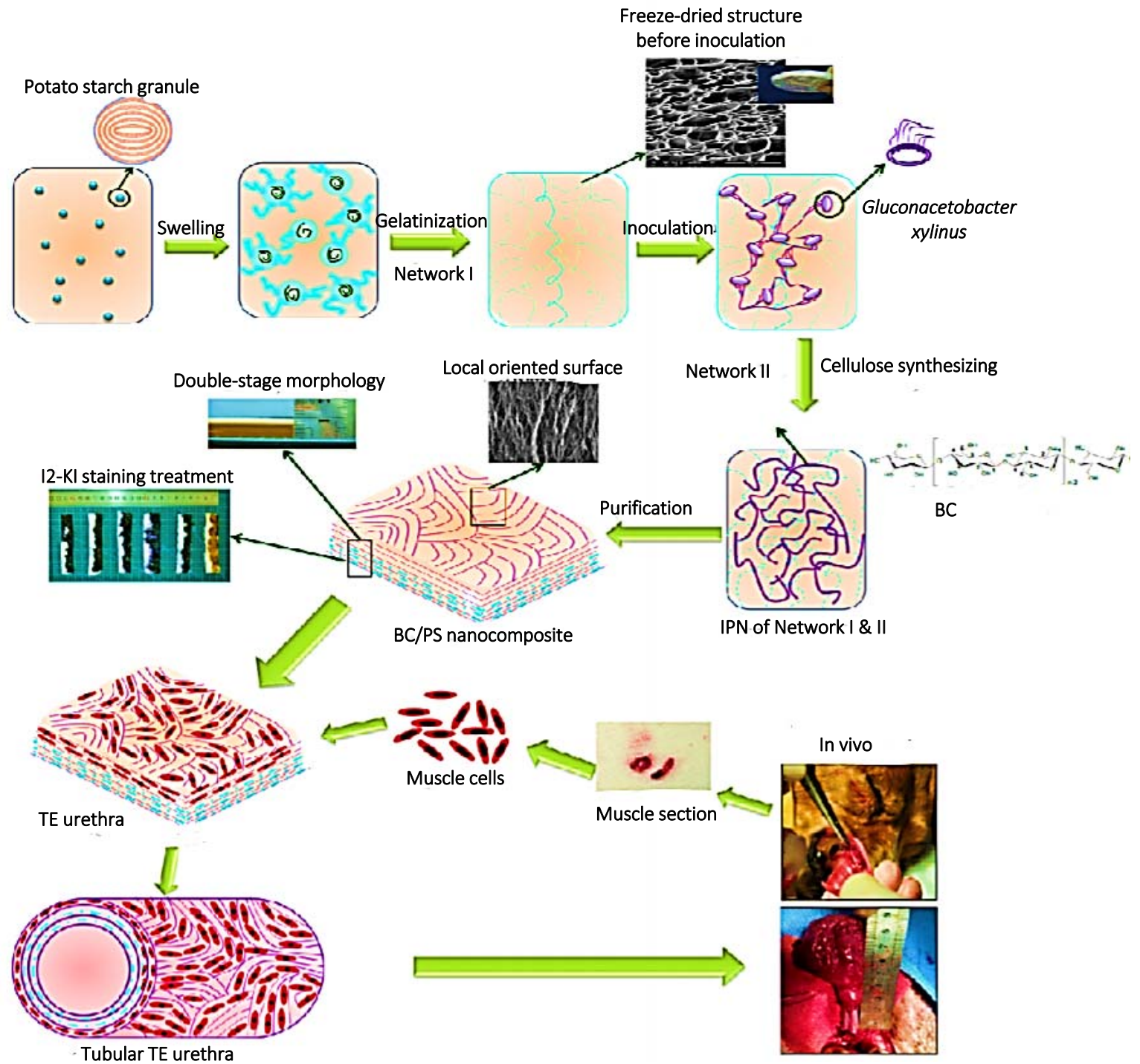

Figure 3. Schematic illustration of biosynthesis of BC/potato starch (PS) composites and experimental design in fabrication of tissue engineered urethra. Reprinted with permission from Ref. [10] Copyright (2016) American Chemical Society. 
BC fibre formation is influenced by the culture media (carbon and nitrogen source), culturing conditions (temperature and $\mathrm{pH}$ ), degree of aeration, stirring rate, and cultivation time. As previously mentioned, the presence of additives can significantly alter and adjust the quality and ultimate properties of $\mathrm{BC}$ product [11]. It was observed that under agitated conditions, $\mathrm{BC}$ forms as irregular grains, star-shaped and fibrous strands, and also have a tendency to form highly branched, cross-linked structures [12]. In a paper by Fijałkowski et al. [13] the BC product was obtained under rotating magnetic field; resulting product demonstrate lower density, higher water absorption capacity, and significantly reduced microfibrils association compared to the unexposed control. A rotating magnetic field significantly increased the amount of wet cellulose particles obtained, but reduced the weight and thickness of dry cellulose. Gao et al. recently described [14] a new way of BC modification by modifying its building block, i.e., glucose. Before use in the culture medium, the glucose was derivatised using highly fluorescent compound (i.e., 6-carboxyfluorescein, 6CF) and used as a new substrate for fermentation with K. sucrofermentans. The fluorescence intensity of final product was found linearly dependant and adjustable with the concentration of the 6CF-modified glucose in the culture medium. Bianjing et al. [15] show the inclusion of fluoride ions during the biosynthesis of BC and investigate their influence on BC yield, morphology and other properties. A decrease in yield but an increase in Young's modulus, retention of crystallinity and a significant change in morphology were demonstrated. The mechanism underlying the effect on $\mathrm{BC}$ processing is H-bone acceptor action of fluoride ion, which competes with the hydroxyl and acetal oxygen atoms of cellulose. Same keeps the polysaccharide chains on distance to the extent that cellulose network breaks down, while strong ion-dipole interactions are formed between the fluoride and cellulose hydroxyls.

Ultrasonic treatment of $\mathrm{BC}$ membranes is ex situ, post-synthetic modification pathway, which, beside physical properties (e.g., roughness), also affects the temperature of pyrolysis onset, shifting the value from $208^{\circ} \mathrm{C}$ to $250-268^{\circ} \mathrm{C}$, Ref. [16]. Same type of treatment was found to be a potentially attractive approach for increasing the viscosity, mechanical properties, and swelling capacity of BC. In a study by Paximada et al. Ref. [17], BC suspensions were treated with ultrasound at a frequency of $20 \mathrm{kHz}$, a final nominal power of $82 \mathrm{~W}$ and different periods ( $0-5 \mathrm{~min})$. The longer periods $(5 \mathrm{~min})$ increase the crystallinity of the cellulose and the entangled fibrils, while a short treatment $(1 \mathrm{~min})$ was advantageous for the $\mathrm{BC}$ suspensions, as the fibrils could be reduced to half of their initial value due to their collapse.

To induce their biodegradability BC nanofibrils were modified by means of gamma irradiation. Study by Darwis et al. [18] show that an irradiated BC membrane with dose of $25 \mathrm{kGy}$ and $50 \mathrm{kGy}$ immersed in a simulated body fluid (SBF) solution, reached $18 \%$ and $25 \%$ weight loss in 6 months period, in contrast to a degradation resistant, non-irradiated BC. Gamma irradiation significantly affects the tensile strength, particularly after immersion in the SBF solution, mainly due to loosening of the fibril network and the release of small molecular weight fractions.

$\mathrm{BC}$ demonstrate very low degradation rate in vivo. The main reason behind is high crystallinity of $\mathrm{BC}$, as well as absence of the cellulose degrading enzymes in human body to carry out the hydrolysis on $\beta-(1,4)$ glycosidic bonds. BC implants show only slow, non-enzymatic hydrolysis [19], which depends on the chemical components of a main chain and side groups, the state of aggregation and morphology, the hydrophilic-hydrophobic balance, the surface and other factors. This is advantageous for certain applications, but restricts the use in native form when applications in regenerative medicine are intended. Oxidation by sodium periodate [20], nitrogen dioxide [21], or immobilization of the enzyme cellulase [22] are among the reported approaches to trigger the biodegradation of $\mathrm{BC}$, where final degradation product (i.e., glucose) is considered harmless, which is ideal for bioresorbable purposes in many medical applications.

The chemical modifications of $\mathrm{BC}$ utilise the abundant hydroxyl groups, as typical for all cellulosic materials and same include oxidation, etherification, esterification, carbamation and amidation (Figure 4), all resulting in formation of reactive functional and charged groups, such as sulfate, carboxyl, aldehyde, phosphate, amino and thiol groups. Among all, the acetylated BC attract significant interest 
as non-cytotoxic material for cosmetic products, disinfectants, as well as a platform for further coupling (e.g., drugs, bioactives), for use in drug delivery.

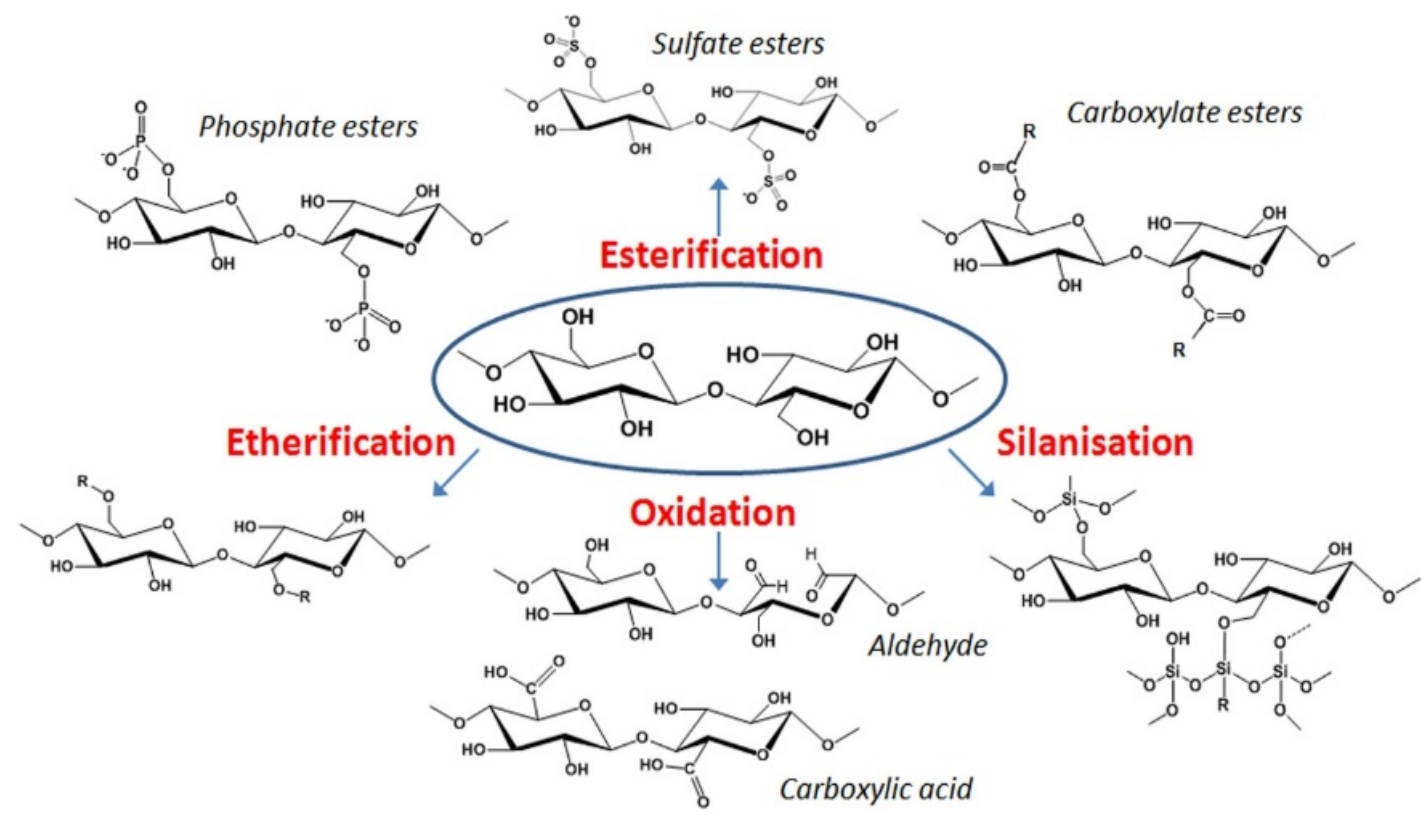

Figure 4. Chemical modifications of BC. Reprinted with permission from [23]. Copyright (2017) Elsevier.

The 'nanofication' of BC, as recently introduced term in review of Choi et al. [24], comprises the downstream BC processing by acid, enzymes and ionic liquids, used to transform the long nanofibrils into nano-sized particles with higher crystallinity than initial BC product. The processing of BC crystals is usually performed by acid hydrolysis (hydrochloric acid, sulphuric acid, phosphoric and hydrobromic acids), wherein, similarly to the formation of nanocrystals from plant cellulose, the amorphous regions are hydrolysed. By this, hydrolytic cleavage of glycosidic bonds is enhanced, thereby releasing individual crystallites from the remaining intact crystalline regions of high acid resistance. Such crystal-like forms of BC have been identified as more convenient for drug delivery formulations, e.g., nucleic acid delivery systems (Figure 5) [25].

$\mathrm{BC}$ can be suspended by mechanical means and further mixed with hydrocolloids. Examples are guar gum and HA, where the resulting bio nanocomposite films have been further coated with collagen to induce their bioactivity and render them unusable for medical applications, such as wound dressings, scaffolds for regenerative medicine and systems for drug delivery and sustained release) [26].

The biological 'inertness' of BC may arise as an issue in certain applications where bioactivity is required; the absence of bioactivity means the absence of cell recognition units to attract (human) cells to attach; but it also means the absence of any active function vis-à-vis an organism, which may also be desirable, such as antimicrobial activity. The combination with materials of choice, e.g., bio- and synthetic polymers and inorganic compounds, is a general approach to elicit certain functions for a targeted application, as shown in Table 1.

Table 1. Material use in BC-based nanocomposites, the modification route and biomedical application.

\begin{tabular}{clcc}
\hline Material & Brief Description of Modification/Processing Procedure & Application & Ref \\
\hline Gelatin (GEL) & $\begin{array}{l}\text { BC oxidation (by sodium periodate, } \mathrm{NaIO}_{4} \text { ) and chemical } \\
\text { coupling, followed with freeze-thawing. }\end{array}$ & $\begin{array}{c}\text { Guided tissue } \\
\text { regeneration } \\
\text { membrane }\end{array}$ & {$[20]$} \\
\hline
\end{tabular}


Table 1. Cont.

\begin{tabular}{|c|c|c|c|}
\hline Material & Brief Description of Modification/Processing Procedure & Application & Ref \\
\hline Collagen & $\begin{array}{l}\text { - Physical mixing of BC slurry and collagen solution, } \\
\text { and subsequent freeze-drying. } \\
\text { - Chemically modified by Malaprade and Schiff-base } \\
\text { reactions and prepared in form of 3D microspheres. }\end{array}$ & $\begin{array}{l}\text { Bone tissue- } \\
\text { engineered } \\
\text { scaffold }\end{array}$ & $\begin{array}{l}{[27]} \\
{[28]}\end{array}$ \\
\hline $\begin{array}{l}\text { Collagen/ } \\
\text { fibrinogen }\end{array}$ & - Cell derived proteins after fibroblast seeding. & $\begin{array}{l}\text { Soft tissue } \\
\text { regeneration }\end{array}$ & [29] \\
\hline Chitosan & $\begin{array}{l}\text { - Immersion in chitosan solution, followed } \\
\text { by freeze-drying. } \\
\text { - Electrostatic coupling of oxidised BC with chitosan } \\
\text { and collagen. }\end{array}$ & $\begin{array}{l}\text { Antimicrobial, } \\
\text { wound dressing } \\
\text { Haemostasis and } \\
\text { wound healing }\end{array}$ & $\begin{array}{l}{[30]} \\
{[31]}\end{array}$ \\
\hline Chitin & $\begin{array}{l}\text { Metabolic engineering of } \mathrm{BC} \text { for introduction of } \\
\mathrm{N} \text {-acetylglucosamine residues. }\end{array}$ & $\begin{array}{l}\text { Non specified } \\
\text { biomedical } \\
\text { applications }\end{array}$ & [32] \\
\hline $\begin{array}{l}\text { Carboxymethyl } \\
\text { cellulose }(\mathrm{CMC})\end{array}$ & $\begin{array}{l}1 \% \text { of } C M C \text { with different degree of substitution was } \\
\text { added during inoculation. Drug (methotrexate) was } \\
\text { loaded by immersion, after the oven drying. }\end{array}$ & $\begin{array}{l}\text { Drug delivery for } \\
\text { the topical } \\
\text { treatment of } \\
\text { psoriasis. }\end{array}$ & [33] \\
\hline Alginate & $\begin{array}{l}\text { Mixture for 3D printing, including } \\
\text { 2,2,6,6-tetramethylpiperidine-1-oxyl (TEMPO)-oxidised } \\
\text { BC and laponite nanoclay. }\end{array}$ & $\begin{array}{l}\text { Non specified } \\
\text { biomedical } \\
\text { application }\end{array}$ & [34] \\
\hline $\begin{array}{l}\text { Hyaluronic acid } \\
\qquad(\mathrm{HA})\end{array}$ & $\begin{array}{l}\text { - } \% \text { HA dispersion was added to the fermentation } \\
\text { process at different time points (first day, third and sixth } \\
\text { day) after the start of fermentation. } \\
\text { - BC membrane was soaked into the solution of HA- } \\
\text { 1-Ethyl-3-(3-dimethylaminopropyl)carbodiimide (EDC) } \\
\text { derivative or first in HA and after in EDC. }\end{array}$ & $\begin{array}{l}\text { Scaffolds for } \\
\text { tissue } \\
\text { engineering }\end{array}$ & $\begin{array}{l}{[35]} \\
{[36]}\end{array}$ \\
\hline $\begin{array}{l}\text { Chondroitin } \\
\text { sulfate }\end{array}$ & In situ addition of chondroitin sulphate. & Dental scaffold & [37] \\
\hline Keratin & $\begin{array}{l}\text { Keratin/BC mats and thermosensitive hydrogel particles } \\
\text { (triblock copolymers conjugated with tragacanth gum) } \\
\text { were prepared by electrospinning and electro } \\
\text { spraying techniques. } \\
\text { - In situ processing: filter sterilised keratin }(3 \% w / v) \text { was } \\
\text { added to culturing medium; ex situ processing: keratin } \\
\text { was impregnated on BC at concentration of } \\
10-15 \mu \mathrm{L} / \mathrm{cm}^{2} \text {. }\end{array}$ & $\begin{array}{l}\text { Wound healing } \\
\text { Skin tissue } \\
\text { engineering }\end{array}$ & $\begin{array}{l}{[38]} \\
{[38]}\end{array}$ \\
\hline $\begin{array}{l}\text { Graphene oxide } \\
\text { (GO) }\end{array}$ & $\begin{array}{l}\text { - GO suspension }\left(0.2 \mathrm{mg} \mathrm{mL}^{-1}\right) \text { was added to the } \\
\text { culture medium. } \\
\text { - Dry BC membranes were cut into small pieces and } \\
\text { crushed by high speed homogeniser. BC/GO nanosheets } \\
\text { composite was synthesised by a sonochemical method, } \\
\text { and films were freeze-dried. } \\
\text { - One-step in situ biosynthesis by adding GO suspension } \\
\text { into the BC culture medium. }\end{array}$ & $\begin{array}{c}\text { Drug delivery } \\
\text { Antibacterial, } \\
\text { biomedical } \\
\text { application } \\
\text { TE scaffold }\end{array}$ & $\begin{array}{l}{[39]} \\
{[40]} \\
{[41]}\end{array}$ \\
\hline $\begin{array}{l}\text { Titanium dioxide } \\
\qquad\left(\mathrm{TiO}_{2}\right)\end{array}$ & $\begin{array}{l}\text { Impregnation of } \mathrm{BC} \text { sheets in } 1 \% \text { aqueous suspension of } \\
\mathrm{TiO}_{2} \text { nanoparticles; nanocomposites were used in wet or } \\
\text { freeze-dried form. }\end{array}$ & $\begin{array}{l}\text { Wound dressing } \\
\text { for burns }\end{array}$ & [42] \\
\hline Silver (Ag) & $\begin{array}{l}\text { Green synthesis of Ag nanoparticles inside the porous BC } \\
\text { network by UV light irradiation. }\end{array}$ & Wound healing & [43] \\
\hline
\end{tabular}


Table 1. Cont.

\begin{tabular}{|c|c|c|c|}
\hline Material & Brief Description of Modification/Processing Procedure & Application & Ref \\
\hline $\begin{array}{l}\text { Hydroxyapatite } \\
\text { (HAp) }\end{array}$ & $\begin{array}{l}\text { Alternate immersion of } \mathrm{BC} \text { in calcium chloride }\left(\mathrm{CaCl}_{2}\right) \\
\text { and sodium hydrogen phosphate }\left(\mathrm{Na}_{2} \mathrm{HPO}_{4}\right) \text { solutions. } \\
\text { - } \mathrm{BC} \text { pellicles were oxidised by } 1 \mathrm{wt} \% \text { sodium } \\
\text { hypochlorite }(\mathrm{NaClO}) \text { solution; } \mathrm{HAp} \text { was formed in } \mathrm{BC} \\
\text { by alternating incubation cycles in } 0.05 \mathrm{~mol} \mathrm{~L} \mathrm{~L}^{-1} \mathrm{CaCl}_{2} \\
\text { and } 0.1 \mathrm{~mol} \mathrm{~L}^{-1} \mathrm{Na}_{2} \mathrm{HPO}_{4} \text { solutions at room } \\
\text { temperature for } 24 \mathrm{~h} \text { in each cycle. Incorporation of } \\
\text { osteogenic growth peptide (OGP) and pentapeptide } \\
\text { OGP (10-14) was carried out by adsorption. }\end{array}$ & \multirow[t]{2}{*}{$\begin{array}{l}\text { Bone tissue } \\
\text { regeneration }\end{array}$} & $\begin{array}{l}{[44]} \\
{[45]}\end{array}$ \\
\hline $\begin{array}{c}\text { Calcium } \\
\text { phosphate }(\mathrm{CaP})\end{array}$ & $\begin{array}{l}\text { - Homogenous } \mathrm{BC} \text { suspension was prepared by grinding } \\
\text { the BC mat in distilled water, where } \\
\text { polyvinylpyrrolidone }(\mathrm{PVP}=(0.5 \mathrm{~g}, w / v) \text {, polyethylene } \\
\text { glycol }(\mathrm{PEG})(1 \mathrm{~g}, w / v) \text {, agar }(2 \mathrm{~g}, w / v) \text {, and glycerin } \\
(1 \mathrm{~mL}, v / v) \text { were incorporated. } \mathrm{CaP} \text { was add-it in the } \\
\text { form of } \beta \text {-tricalcium phosphate }(\beta-\mathrm{TCP}) \text { and HAp. } \\
\text { Cross-linking by moist heat and pressure. } \\
\text { - BC used only as sacrificial phase: } \mathrm{BC} \text { membranes were } \\
\text { loaded with CaP by wet chemistry deposition and } \\
\text { subsequently freeze-dried. }\end{array}$ & & $\begin{array}{l}{[46]} \\
{[47]}\end{array}$ \\
\hline $\begin{array}{l}\text { Mont-morillonite } \\
\text { (MMT) }\end{array}$ & $\begin{array}{l}\text { - BC sheets were treated with } 1 \%, 2 \% \text { and } 4 \% \\
\text { MMT suspensions. } \\
\text { - Ex situ: immersion of BC membrane into MMT } \\
\text { suspension and in situ addition into culture medium. }\end{array}$ & $\begin{array}{l}\text { Non specified } \\
\text { biomedical } \\
\text { application }\end{array}$ & $\begin{array}{l}{[48]} \\
{[49]}\end{array}$ \\
\hline \multirow{3}{*}{ Poly(acrylamide) } & $\begin{array}{l}\text { - BC matrices immersed into aqueous solution containing } \\
55 \mathrm{wt} \% \text { of acrylamide for } 16 \mathrm{~h} \text {. } \\
\mathrm{N}, \mathrm{N}^{\prime} \text {-methylenebisacrylamide was used as the } \\
\text { crosslinking agent, and cobalt (III) acetate as initiator. }\end{array}$ & $\begin{array}{l}\text { Non specified } \\
\text { biomedical } \\
\text { application }\end{array}$ & [50] \\
\hline & - In situ polymerisation of acrylamide in BC emulsion. & $\begin{array}{l}\text { Bone and } \\
\text { cartilage repair }\end{array}$ & [51] \\
\hline & $\begin{array}{l}\text { - Graft polymerisation of acrylamide on BC solubilised in } \\
\text { an sodium hydroxide (NaOH)/urea solvent system and } \\
\text { on dispersed BC by using } \mathrm{N}, \mathrm{N}^{\prime} \text {-methylenebisacrylamide } \\
\text { as a crosslinker under microwave irradiation. }\end{array}$ & $\begin{array}{l}\text { Oral drug } \\
\text { delivery }\end{array}$ & [52] \\
\hline $\begin{array}{l}\text { Poly(lactic acid) } \\
\qquad \text { (PLA) }\end{array}$ & $\begin{array}{l}\text { BC sheets were dried and coated with the PLA solution, } \\
\text { followed by loading of antiseptic benzalkonium chloride. }\end{array}$ & $\begin{array}{l}\text { Antimicrobial } \\
\text { and acute wound } \\
\text { healing }\end{array}$ & [53] \\
\hline $\begin{array}{l}\text { Polyvinil alcohol } \\
\text { (PVA) }\end{array}$ & $\begin{array}{l}\text { Purified BC membranes were immersed in a } 10 \% \text { PVA } \\
\text { solution for } 24 \mathrm{~h} \text { at } 80{ }^{\circ} \mathrm{C} \text {, frozen at }-20^{\circ} \mathrm{C} \text { for } 24 \mathrm{~h} \text { and } \\
\text { thawed at room temperature in distilled water. }\end{array}$ & $\begin{array}{l}\text { Non specified } \\
\text { biomedical } \\
\text { application }\end{array}$ & [54] \\
\hline Acryic acid (AA) & $\begin{array}{l}\text { Hydrogel formed from } 1 \% w / v \text { BC solution was mixed } \\
\text { with AA solution, subsequent electron beam irradiation; } \\
\text { material have incorporated human epidermal } \\
\text { keratinocytes and human dermal fibroblasts. }\end{array}$ & Wound dressing & [55] \\
\hline
\end{tabular}




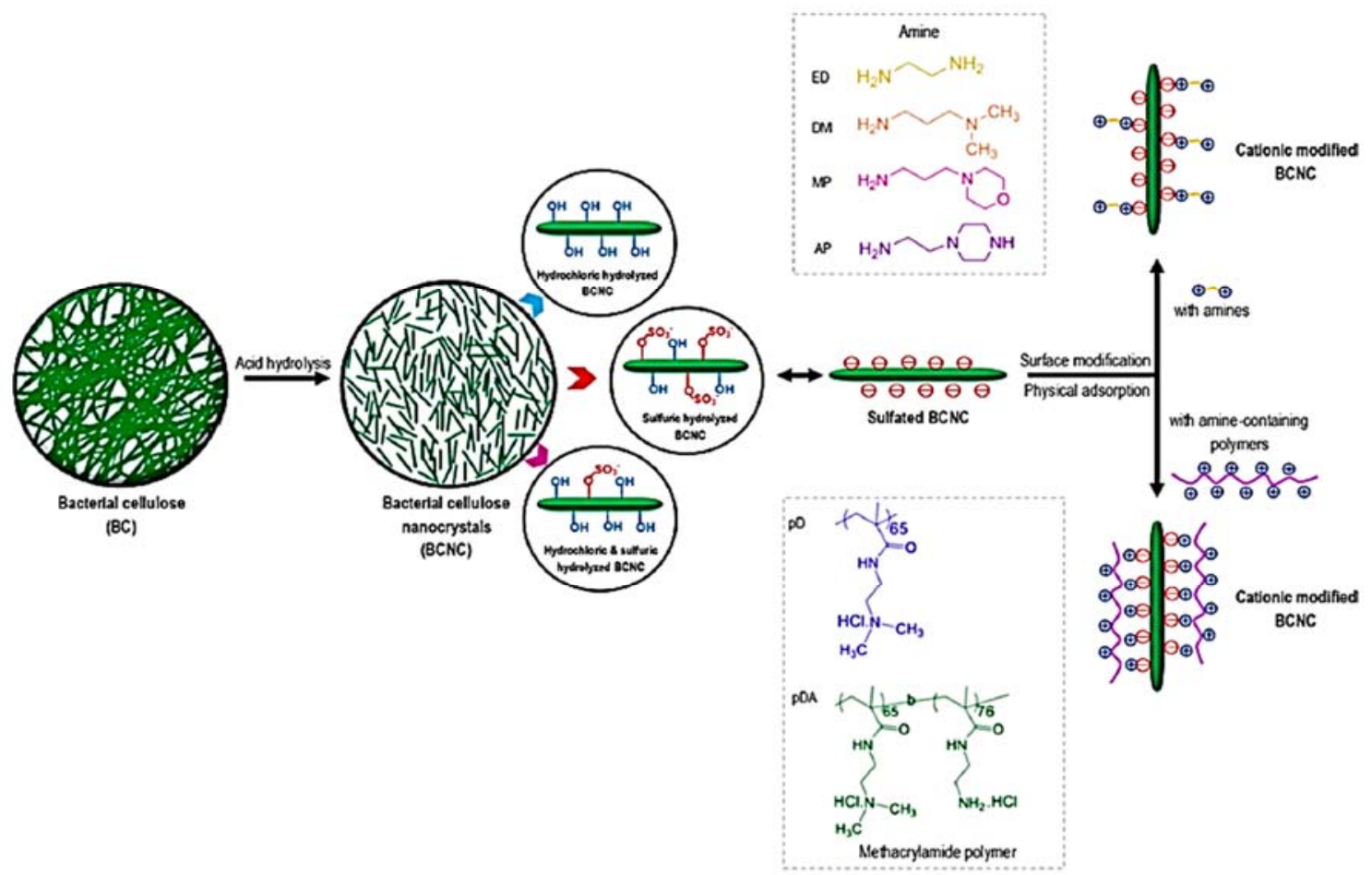

Figure 5. Processing of BC crystals by acid hydrolysis and cationic surface modification of sulfated BC by physical adsorption using amines and amine-containing polymers. Reprinted with permission from [25]. Copyright (2018) American Chemical Society.

\section{BC In Vitro/In Vivo Biocompatibility and Biomedical Applications}

Biocompatibility in the broadest sense refers to the ability of a biomaterial to perform its intended function in relation to a medical therapy without causing adverse or systemic effects in the recipient or beneficiary of that therapy, but to produce the most appropriate beneficial cellular or tissue response in that specific situation and to optimise the clinically relevant performance of the therapy' [56].

Because of the combination of exceptional properties offered within a single material, such as ultra-high purity, low coefficient of friction, appropriate surface topography, chemistry and hydrophilicity, BC-based materials are widely used in biomedical applications [22]. BC is generally considered non-cytotoxic in vitro as well as non-immunogenic [23]. According to a review by Petersen and Gatenholm [57] the biocompatibility of BC can be attributed to its similarity to collagen in term of fibril diameter $(\sim 100 \mathrm{~nm})$ and assembling mode, i.e., extracellular synthesis out of monomer precursors into long polymer chains. Another advantage is that BC can be purified to rich endotoxin levels below 20 (endotoxin units/device), as approved limit for implant by the Food and Drug Administration (FDA). Ref. [58] For medical applications, 'generally accepted as safe' (GRAS) certification by the FDA is required. The GRAS status is often restricted for bacterial biopolymers (as BC), mainly because of the presence of host cell-derived contaminants, such as endotoxins, which negatively affect product quality.

Numerous studies demonstrate the compatibility of BC with various human cells that can grow and multiply in the presence of BC, such as smooth muscle cells [10], chondrocytes [59], fibroblasts [60], keratinocytes [61], osteoblasts [62], human umbilical vein endothelial cells [63], bone marrow mesenchymal stem cells (MSCs) [64], adipose-derived MSCs [65] etc. The BC potency to stimulate collagen-I formation by MSCs was identified by multiphoton microscopy [66]. The seeded MSCs adhered rapidly and firmly and grew into multilayers, demonstrating the ability of BC to stimulate MSCs for osteogenic differentiation.

Some modifications even improve cell affinity and viability; grafting of a carboxymethyl group on BC improves the initial cell adhesion and also causes a reduced inflammatory response in vivo, Ref. [67]. Scaffolds based on BC and BC/hyaluronic acid (HA) or gelatin (GEL) have been investigated 
in contact with human pulp stem cells. Confocal microscopy images demonstrate well distributed and adhered cells on both (BC/HA and BC/GEL) type of scaffolds, demonstrating potential for stem cell therapy [68].

Group of Fu et al. [69] synthesised BC films by 7 days static culturing in 24 and 96-well plates. The cell evaluation studies clearly demonstrate better proliferation and adhesion of mouse embryonic fibroblasts (NIH/3T3 line) cultivated on their surfaces, in comparison with control group. The in vivo studies performed on large skin areas showed faster tissue regeneration in BC group, with moderate inflammation reaction, being localised to epithelial tissues.

The group of Pertile et al. [70] found that BC calcified under long-term in vivo exposure. In the same study, the implanted BC caused a mild, benign and declining inflammatory response, which did not induce a foreign body reaction, while four months after implantation, intracellular accumulation of BC nanofibers in subcutaneous foamy macrophage aggregates was observed. Degree of calcification was directly related to the porosity of the material and the duration of exposure. It was speculated that such undesirable fate of implanted biomaterial, may also depend on the tissue type into which the biomaterial is implanted.

\subsection{BC in Wound Dressing}

The light and transparent native BC membrane, offer extraordinary combination of mechanical properties with a stress-strain behaviour similar to soft tissue, such as skin, which makes this material very perspective for such applications, as already summarised in several reviews [71-73]. The easy of inspection (due to its transparency), pain relief effect, reduction of infection with exudate retention capacity, reduced healing time, adherence to the wound and easy removal after improved epithelialisation, are some of superior properties BC over the conventional dressings. BC dressings form a dense physical barrier against microbial contamination and additional injury, while allowing gas exchange. $\mathrm{BC}$ is also flexible and can adapt to the contour of a wound, reducing the risk of harmful microbial contamination. They are available in any size and shape, and even large wounds can be covered with a single membrane.

An interesting feature of BC membranes is that they interact differently with wounded and intact skin. Indeed, the segment that comes into contact with intact skin dries out and forms a thin cellophane-like layer that adheres to the outermost layer of the epidermis (stratum corneum). On the other hand, the central membrane segment in contact with the wound remains moist, thus preventing maceration of the skin around the wound caused by long-term exposure to moist dressings. Using a microfluidic-based in vitro wound healing model, Ying et al. [74] showed that the underside of the BC film can better promote cell migration to facilitate wound healing. In addition, the full-thickness skin wounds of Wistar rats showed that the wound covered by the underside of the BC film had a faster healing rate and a lower inflammatory response compared to gauze and the top of the BC film.

Wound healing consists of complex cellular and biochemical events that can be divided into several overlapping stages, i.e., homeostasis, inflammatory response, cell proliferation and synthesis of the extracellular matrix and the posterior period-maturation or remodelling Ref. [75]. Typically, there are five types of wounds: abrasions, lacerations, punctures, lacerations and burns [76] and in almost all types, wound exudates contain elevated levels of reactive oxygen species, cytokines and proteolytic enzymes. Presence of exudates reduced the concentration of proteinase inhibitors and growth factors, leading to tissue degradation and disruption of inflammatory phase, as well as whole healing cascade. Further one, the optimal wound dressing should provide a moist environment (for improved re-epithelisation and reduced scarring), absorb exudates during the inflammatory phase, act as a barrier to infection and fluid loss, cover the wound lightly and tightly and allow the delivery of drug or medication to the wound bed. Water holding capacity, water release rate and water vapour transmission rate are among the most important quantitative physical parameters important for use as a wound dressing and are strongly dependent on available surface area, pore size distribution, etc. [77]. 
In a study of Moraes et al. [78], a wound dressing based on BC/collagen hydrogel was compared with commercial collagenase ointment, both applied on rat dorsum wound. The composite hydrogel was found to promote better wound healing than collagenase and the control group. Khan et al. [79] recently reported preparation of highly microporous, surface-modified, BC scaffolds for skin regeneration, wherein round shaped GEL microspheres prepared with a water-in-oil emulsion method were used as porogen for porosity improvement.

BC doped with resveratrol was prepared by group of Meng et al. [80], as a wound healing dressing. This polyphenolic compound, naturally found in red grape skins, red wine, peanuts, cranberries and other fruits, is reported to have low toxicity and is well tolerated in humans. The same was found to highly regulate endothelial nitric oxide synthase and vascular endothelial growth factor and promotes angiogenesis in wound healing experiments. 3D shaped, $\mathrm{BC} /$ resveratrol scaffolds preserved the normal collagen bundling pattern and induced re-epithelialization in defective rat epidermis, suggesting that the material provides a biocompatible environment for stem cell attachment and growth and promotes epithelial regeneration during wound healing.

BC and copolymer of 3-hydroxybutyric acid and 4-hydroxybutyric acid-a biodegradable polymer of microbial origin was combined in a hybrid dressing [81]. Two groups of hybrid membranes were investigated: BC loaded with a drug that promotes wound healing (actovegan), and BC colonised with epidermal cells different from multipotent MSCs. The in vitro study showed that the most effective scaffolds for fibroblast growth were composite BC-based films loaded with actovegin. In vivo tests using an animal model with third-degree skin burns showed a higher efficiency of both hybrids compared to a commercial wound dressing.

In the work of Khamrai et al. [82] BC was ionically modified using 2-(methacryloyloxy) ethyltrimethylammonium chloride (PMTAC) and poly (sodium 4-vinylbenzene sulfonate) (PSS) as positively and negatively charged polymers, respectively. Modified BC was further incorporated into a GEL-based composite hydrogel, where the interlocking network was formed by the ionic interaction with the oppositely charged, modified BC. The hydrogel patch was loaded with curcumin, which enabled the wound healing activity, which was investigated with the NIH 3 T3 fibroblast cell line. The same patch exhibits antimicrobial activity and self-healing capacity.

Recent clinical studies have demonstrated the efficacy of BC wound dressing in human burn wounds. Compared with other commercial wound dressing products, the BC-based Biofill demonstrate efficient pain relief and reduction in postoperative discomfort, faster healing, lack of scarring as well as high time- and cost efficiency of the whole clinical treatment. In addition, Biofill protects the wound from infection and is permeable to fluids and gases and acts as a suitable artificial skin. Other products from the same (BioFill, Brazil) company are Dermafill, BioProcess and Nexfill. Xylos Corporation (Langhorne, PA, USA) is another manufacturing company with XCell and Prima CelTM products used as a wound dressing for venous ulcer wounds that promote autolytic debridement, relieve pain and accelerate granulation. Technical University of Lodz develop and marketed two known brands, namely CelMatC and CelMatMG. Polyhexamethylene biguanide (PHMB)-supplemented BC (Suprasorb X+ PHMB) is a commercial product of the company Activa Healthcare, L\&R Company (Needwood Burton on Trent, United Kingdom), which is marketed as a wound dressing that can be used in moderately exuding, infected or critically colonised wounds. Ref. [83] Membracel is a commercial product of the company Vuelo Pharmathat and is marketed as a temporary skin replacement for ulcers, burns and lacerations. Ref. [84] Nanoderm and Nanoderm Ag from Axcelon Biopolymers Corp (Ontario, Canada). are antimicrobial dressings that prevent infections; Nanoskin from Innovatec, which is intended to be used as a blood vessel substitute; and Linfatics, lesions of the glume, facial peeling, infectious dermolysis, abrasion of tattoos and chronic ulcers, which allow the release of gases while inhibiting the entry of microorganisms. EpiProtect ${ }^{\circledR}$ is a product of S2Medical AB (Linköping, Sweden), which has recently been used to heal paediatric patients with burns [85]. 


\subsection{Antimicrobial Activity in $B C$}

$\mathrm{BC}$ provide physical barrier that can reduce the penetration of bacteria into the tissue, however, in its native form do not offer any antimicrobial action. To elicit bioactivity towards different bacteria, various modification routs have been proposed or specific compounds have been added to deliver BC products, especially wound dressings, with antimicrobial and/or anti-inflammatory properties. The antibacterial BC composites can be prepared in situ by adding partially deacetylated chitosan nanocrystals to the culture medium or by post-synthetic modification and mixing of both suspensions [86].

The integration of antibiotics into BC dressings is a most common approach. In the work of Laçin [87], the antibiotic chloramphenicol was integrated into oxidised BC membranes, resulting in a prolonged antimicrobial effect and improved adhesion and proliferation of fibroblasts. In the work of Ye et al. [88], the $\mathrm{BC}$ sponge was formed by grafting amoxicillin onto regenerated $\mathrm{BC}$, which provide antibacterial activity against Gram+ and Gram- bacteria without toxicity to host cells. Group of Rouabhia [89] prepare gentamicin-activated $\mathrm{BC}$ membranes by chemical grafting of arginine-glycine-aspartic acid-cysteine (RGDC) peptides, and using the coupling agent 3-aminopropyltriethoxysilane. Resulting gentamicin-RGDC-grafted BC membranes, were found non-toxic to human skin fibroblasts and provide a bactericidal effect against Streptococcus mutans. In a study by Junka et al. [90], BC saturated with gentamicin show prolonged antibiotic release and significantly reduce the levels of biofilm-forming pathogens, Staphylococcus aureus and Pseudomonas aeruginosa, resulting in low in vitro cytotoxicity to osteoblast cell lines.

In addition to the antibiotics inclusion, the chemical modification of $\mathrm{BC}$ can ensure prolonged antimicrobial activity and serve as an alternative method for activating the structure against immune-reactive bacteria, without the addition of exogenous components Ref. [71]. The chemical grafting of aminoalkyl groups onto the surface of their $\mathrm{BC}$ network as a mimetic structure for chitosan was investigated in study of Fernandes et al. Ref. [91]. The BC- $\mathrm{NH}_{2}$ membranes obtained were lethal to Staphylococcus aureus and Escherichia coli and non-toxic to MSCs derived from human adipose tissue. Another efficient examples for BC are the introduction of multicationic triazine benzyl groups [92], the introduction of functional hydrophobic sites on the BC surface, etc.

Recent work by Wang et al. [93] has demonstrated the covalent transplantation of the photosensitiser Hypocrellin onto BC. The results showed a $99.5 \%$ reduction of Staphylococcus aureus under illumination, while no statistically significant inactivation of Escherichia coli was observed. The latter was inactivated by potentiation by $99.1 \%$ ( $2 \log$ units). Potassium iodide is due to short-lived reactive iodide radicals, which are the most important biocidal agents. Indirect cytotoxicity tests using mouse skin fibroblast cells (L929) showed no changes in cell viability, indicating a lack of leachable components (e.g., unreacted coupling agent or hypocrellin) that could be cytotoxic to mammalian cells. A study by Vismara et al. [94] describes the manufacture of BC-based wound dressings in which BC has been modified by grafting glycidyl methacrylate crosslinked with ethylene glycol dimethacrylate through a Fenton-type radical process involving the generation of carbon-cantered cellulose radicals that are trapped by methacrylate structures. Modified BC was further loaded with antimicrobial agents, vancomycin and ciprofloxacin, which limit colonization by Staphylococcus aureus and Klebsiella pneumoniae.

In Maneering's work [95] the BC membranes were immersed in silver nitrate solution and then the silver ions $(\mathrm{Ag}+)$ were reduced to $\mathrm{Ag} 0$ by sodium borohydride. The impregnated $\mathrm{BC}$ membranes were then freeze-dried; material demonstrate strong activity against Escherichia coli and Staphylococcus aureus. Similar findings were shown by the introduction of copper sulfate into BC enriched with alginate and chitosan [96]. In the work of Ataide [97] BC was immersed in a sterilised bromelain solution and incubated for $24 \mathrm{~h}$ at room temperature. Bromelin is a protease found in pineapple pulp and is used in medicine for its anti-inflammatory and anticancer properties, promotion of cell apoptosis, etc. Interestingly, the antimicrobial activity of bromelin increased after its incorporation in BC membranes: in Escherichia coli and Pseudomonas aeruginosa, the bromelain-releasing solution MIC was six times 
higher than the original solution MIC, while in Staphylococcus aureus, the bromelain-releasing solution MIC was 12 times higher than the original solution MIC.

A mussel mimetic transdermal patch was prepared from carboxylated BC and dopamine (DOPA) by amidation reaction. BC/DOPA patch provide antimicrobial action against both Gram+ (Staphylococcus aureus and Lysinibacillus fusiformis) and Gram- (Escherichia coli and Pseudomonas aeruginosa) bacteria. The in vitro wound healing tests, utilising NIH 3T3 cell line and the human lung epithelial cell line A549 show that the presence of reduced graphene oxide (rGO) and Ag nanoparticles in the composite film further accelerates the wound healing process [98].

\subsection{BC as Blood Brain Barrier (Bbb) Model}

The BBB is a dynamic barrier in the brain that protects the brain from toxic substances arriving from the bloodstream. As such, plays an important role in maintaining homeostasis in the central nervous system. Because of its neuroprotective function, the BBB is also an obstacle for various drugs for the treatment of neurodegenerative diseases and brain tumours to enrich the central nervous system from the bloodstream. This is of particular interest for the pre-development of in vitro models of the $\mathrm{BBB}$, especially due to its animal-free concept.

The use of the $\mathrm{BC}$ in this area is not very common, even its use as a basement membrane is a promising approach, because of low (non) degradability of BCunder culturing conditions and its nano-porosity $(200 \mathrm{~nm})$, which allows cell attachment while preventing cells from changing compartments. In recent work by Bayir et al. [99], unmodified BC has been used as a reliable basement membrane for BBB models in pharmaceutical research (Figure 6). Measurements of transendothelial electrical resistance (TEER) show that the BC membrane leads to statistically higher TEER values than the standard PET Transwell insert membrane. Validation of the model was performed with sucrose and caffeine, whose permeability values are close to the in vivo values.

\section{Insert Preperation}

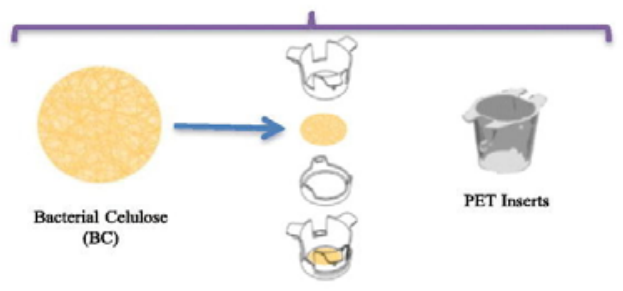

BC Insert

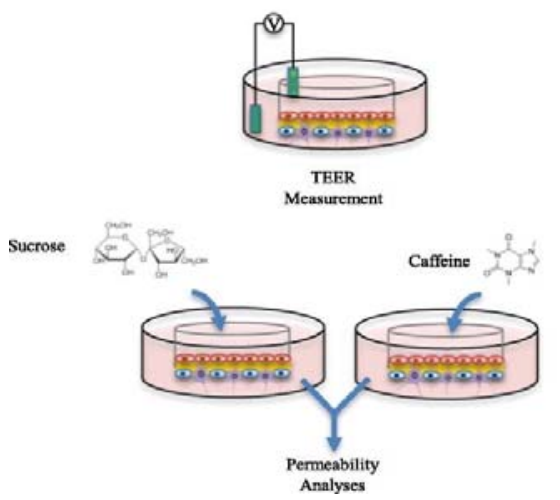

\section{Different Culture Methods}

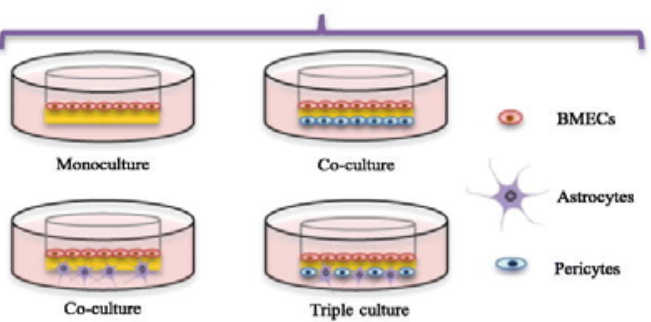

Triple culture

$\sqrt{1}$

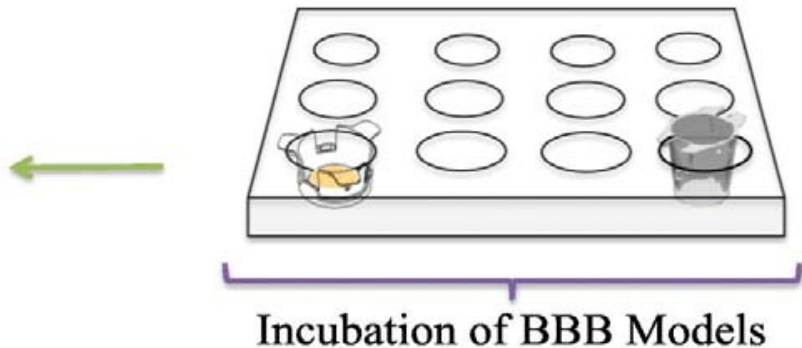

Figure 6. BC used as basement membrane in BBB model. Reprinted with permission from [99]. Copyright (2019) Elsevier. 


\subsection{BC in Dentistry}

$\mathrm{BC}$ is a mucoadhesive, flexible and soft material, which makes it a good candidate for dental applications. BC can be used as a wound dressing for the palate in mucosal grafts or as a cover for extraction sockets [100] and can also be used as a temporary implant in dental extraction sockets or as a membrane for guided tissue regeneration [77].

In dental implant and prosthetic dentistry, the preservation of residual alveolar bone volume after tooth loss is critical, but is often compromised by infections, external injuries, and other lesions. Gengiflex ${ }^{\circledR}$ (a product of Biofill, Brazil) is used in the treatment of periodontal defects. Gengiflex ${ }^{\circledR}$ consists of two layers: The inner membrane is made of $B C$, which makes the membrane rigid, while the outer membrane is chemically modified from alkali cellulose. After Gengiflex ${ }^{\circledR}$ therapy, a complete improvement of the bony defect around a TiAl6V4 implant was reported, but incomplete bone growth was observed in injuries covered with Gengiflex ${ }^{\circledR}$ membranes, resulting in pores and low bone density.

Studies by Weyell et al. [100] have demonstrated the benefits of doxycycline-loaded hydrated and freeze-dried BC in dental therapies such as tooth extraction or mucosal grafting, where the periodate oxidation was investigated towards the modified degradation profile. In addition, native and oxidised doxycycline-loaded BC were tested for infection prophylaxis, with release studies of the drug confirming a comparative biphasic release behaviour.

Group of Jinga [101] showed that the presence of $B C$ nanowhiskers accelerates the curing processes of mineral trioxide aggregate cements, resulting in composites suitable for endodontic application. The same group combined BC powder with silicate cement powder for sustained cell survival and promoted cell proliferation in vitro, demonstrating its potential for application in dentistry [102].

In our recent work [20], we combine BC with GEL to form asymmetric membranes by successive periodate oxidation and a freeze-thaw/carbodiimide crosslinking process, which allows first a Schiff reaction between the respective aldehyde and hydroxyl groups and later GEL stabilisation and microstructuring. The membranes produced no cytotoxic effects on human fibroblasts, MRC- 5 cells, maintained their morphology in direct contact with the membrane, adhered to the GEL porous site while not adhering to the thinly GEL-coated BC side, showed beneficial properties for possible applications of guided tissue regeneration as required in periodontal treatment.

\subsection{BC in Cartilage, Bone and Osteochondral Regeneration}

In bone tissue engineering, ceramics, metals, polymers and composites are most frequent materials of choice. The ceramics, such as hydroxyapatite (HAp) and calcium phosphates (CaP) are most widely used because of their osteoconductive and osteoinductive properties, which are, however, associated with brittleness and low mechanical stability. Metals (e.g., titanium) are biocompatible, but there is increasing concern about dissolved/released metal particles and ions that cause inflammatory reactions around the implant. In particular, the inflammatory cytokine tumour necrosis factor-alpha (TNF- $\alpha$ ) is expressed in the adjacent bone when a titanium implant is used [103]. Synthetic polymers, such as poly (E-caprolactone), poly (lactic acid), poly (glycolic acid) and their copolymers, poly (carbonates) and poly (anhydrides) are often used as tailor-made precursors, with natural polymers, proteins and polysaccharides also playing an important role in this area.

The mechanical properties of $\mathrm{BC}$ give it its use as filler and mechanical enhancer in hard tissue regeneration applications. The elastic modulus of $\mathrm{BC}$, measured by atomic force microscopy was reported to reach $78 \mathrm{GPa}$ and by Raman spectroscopy for individual $\mathrm{BC}$ fibres the $114 \mathrm{GPa}$, which becomes lower when $\mathrm{BC}$ foils are measured (their elastic modulus was reported to be in the range of 15-35 GPa), Ref. [104]. Since BC is considered to be collagen mimetic, the mineralised phase HAp or another $\mathrm{CaP}$ component is often added by three general methods: (i) In situ cultivation of CaPs in culture media; (ii) ex situ synthesis of CaPs in BC fibres or physical mixing of the two materials; and (iii) synthesis of $\mathrm{BC}$ composite from $\mathrm{BC}$ solution [61].

The main limitation of $\mathrm{BC}$ in bone regeneration is its high density and nanoporosity, which limits cell infiltration. Zaborovska et al. [105] reported on the production of porous BC by introducing 
300-500 $\mu \mathrm{m}$ paraffin micro particles during the biosynthesis process. If the macroporous BC was colonised with MC3T3-E1 osteoprogenitor cells, clustering of the cells within the pores and denser mineral deposition occurred as in the control surfaces of the BC. The same approach was used by Andersson, using wax particles of 150-300 $\mu \mathrm{m}$. Joint chondrocytes from young adult patients and neonatal joint chondrocytes penetrated the pores and multiplied, producing glycosaminoglycan (GAG) in the clustered regions [59]. In order to be used as a reinforcement phase as a single nanofiber instead of nanofibrilar network, the BC was broken down by microfluidisation and ultrasound and the chain aggregation was additionally stabilised by CMC polymer. [106]

Pigossi et al. [45] reported on the preparation of BC-HAp composites associated with osteogenic growth peptide (OGP) or pentapeptide OGP (10-14) and their use for bone regeneration in critical size calvarial defects in mice. Three days after operation, the specific bone markers (Runx2, Tnfrsf11b and Bglap) were upregulated by membranes containing the peptides, suggesting an acceleration of osteoblastic differentiation as well as activity. After 60 and 90 days a high percentage of bone formation was observed for membranes based on BC-HAp and BC-HAp OGP (10-14).

In the study by Coelho et al. [107], the BC membrane was associated with HAp and an antibody against bone morphogenetic proteins (anti-BMP-2) (BC-HAp-anti-BMP-2), which do not demonstrate any toxicity, genotoxicity and mutagenicity. The release kinetics of the anti-BMP-2 antibodies detected in vitro gradually reduces the antibody levels so that they decrease by about $70 \%$ in 7 days and by about $90 \%$ in 14 days. BC-HAp-anti-BMP-2 increased the expression of several genes involved in bone repair, increased mineralization nodules and levels of alkaline phosphatase activity.

In the work of Zhu [108], BC was used for the treatment of osteochondral defects (particularly for the cartilage segments) by incorporating $\mathrm{BC}$ into a double-network hydrogel system of two interpenetrating polymer networks consisting of $\gamma$-glutamic acid, lysine and alginate. The results show that the compression modulus of the resulting hydrogel $(0.322 \mathrm{MPa})$ was comparable to that of natural articular cartilage. Martinez et al. [109] demonstrate the efficacy of two-layer BC scaffolds consisting of a dense $\mathrm{BC}$ layer and a macroporous nanocellulose/alginate layer for osteochondral regeneration, whereby the scaffold is colonised with human nasoseptal chondrocytes (NC) and cultivated in vitro for up to 6 weeks. Formed two-layer BC scaffolds have a porosity of $75 \%$ and an average pore size of $50 \pm 25 \mu \mathrm{m}$, were non-pyrogenic $(0.15 \pm 0.09 \mathrm{EU} / \mathrm{mL})$ and non-cytotoxic (cell viability: $97.8 \pm 4.7 \%$ ), provide good mechanical stability and maintain structural integrity. Importantly, they provide a suitable environment for cultured NCs and a combination of isolated NCs and MNCs for cartilage formation in vitro and in vivo.

\subsection{BC in Drug Delivery}

BC's high purity, biocompatibility and unique structural and mechanical properties, as well as its ability to adhere to irregular skin surfaces and high skin tolerance are significant attributes for topical drug delivery systems, Ref. [110]. An important advantage is its high temperature stability, which facilitates its sterilisation by autoclaving. BC has been utilised for administration of antibiotics to the wounds, molecularly imprinted polymeric matrix systems for the enantioselective administration of drugs, support in transdermal drug administration and absorption of residues, administration agents in the treatment of dental canals, as matrices and capsule shells for oral drug administration, protein administration in the colon, etc. However, its highly porous structure can hardly resist the free movement of gasses, solvents and other small molecules, which makes native BC an unsuitable biopolymer for controlled drug delivery. The specific chemical modifications are essential to achieve its conversion into the efficient drug delivery cargo [111].

In the work of Narh et al. [112] inulin was introduced into the fructose permeates of the bacterial strain Gluconacetobacter xylinus to synthesise empty cellulose pockets for the storage of drugs. BC/CMC biocomposites with varying degrees of substitution (from 0.7 to 1.2 ) were loaded with methotrexate (MTX) as an alternative for the topical treatment of psoriasis, Ref. [33]. Study suggests that degree of substitution in CMC is a key factor in modulating BC properties and drug release. Composite films of 
the same composition crosslinked with citric acid were prepared by solution casting and loaded with ibuprofen sodium salt as a non-steroidal anti-inflammatory drug with also analgesic and antipyretic effects, Ref. [113]. Acetylated freeze-dried BC was found to efficiently encapsulate both, the poorly water-soluble drug famotidine and the highly water-soluble drug tizinidine [111]. BC and alginate were mixed by an ex situ method with Ag sulfadiazine payload. Loading BC-alginate scaffolds with varying amounts of doxorubicin reduced the cell viability of the HT-29 human colorectal adenocarcinoma cell line compared to free dox from about 95 to $53 \%$ after $24 \mathrm{~h}$ and from $63 \%$ to $37 \%$ after $48 \mathrm{~h}$, demonstrating the potential for cancer therapies in solid tumours. BC-alginate coacervate films were loaded with doxorubicin by an absorption mechanism. Strong interaction between BC and alginate, creating a highly interpenetrating biopolymeric network that contributes to an improved inclusion and loading capacity of hydrophilic doxorubicin. Other examples of drugs loaded into BC or BC-based composites are bovine serum albumin [114], caffeine, lidocaine, ibuprofen and diclofenac [115], levofloxacin [116], propranolol [117], etc.

Group of Chen et al. [118] develops multifunctional core-shell hybrid microfibers by combining coaxial spinning with a microfluidic device and subsequent dip coating, which contain a hydrogel core of BC and a conductive polymer shell layer of poly (3,4-ethylenedioxythiophene). A diclofenac sodium, was introduced as model drug into the core layer of the microfibers during the synthesis process and its release was enhanced by external electrical stimulation. The resulting hybrid microfibers exhibit a well-controlled microscopic morphology, improved mechanical properties, excellent biocompatibility and electroactivity for PC12 cell cultures, suggesting a potential application for the reconstruction of electrically responsive tissues that mimic muscle fibres or nerve networks.

\subsection{Other Applications of $B C$}

Mesh for hernia treatment. An ideal mesh used in hernia repair must meet several requirements: long-term biocompatibility, mechanical stability with low shrinkage, resistance to infection and seroma formation, avoidance of adhesions and fistulas, and the lowest possible hernia recurrence rate. Recent preclinical studies in Wistar rats with different models of ventral hernia show encapsulation and moderate inflammation, but because of the presence of undesirable adhesions and structural instability and shrinkage of the mesh, future modifications were identified as necessary [119]. In a study of Piasecka-Zelga et al. [120] the bio-modified mesh was formed on commercial polypropylene (PP) mesh coated on one or both sides with chitosan-modified BC. Modified BC and PP fabric were well integrated because of the pre-irradiation of the PP fabric with UV. After implantation, the PP-BC composite mesh induces the least immune reaction to the surrounding tissue, effectively induces tissue remodelling, does not induce allergic or intradermal reactions or pathological changes in internal organs, indicating a better performance than the commercial PP mesh.

In the work of Wang et al. [121], the BC was identified as a promising candidate for the prevention of postoperative epidural fibrosis and adhesion. The membrane consisted of $\mathrm{BC}$ and exosomes of human umbilical cord MSCs, and these show no cytotoxicity in vivo and no inhibitory effect on epidural fibrosis and peridural adhesion.

Artificial cornea. BC's high light transmission, favourable mechanical properties, ability to withstand surgical sutures and intraocular pressure, and biocompatibility make it a potential candidate for a scaffold for keratoplasty. Keratoplasty is a widely used technique for replacing damaged corneas, often associated with side effects such as xerophthalmia, corneal neovascularization, donor shortage and graft rejection. The work of Jia [122] demonstrate that corneal stroma cells can be preserved, grow and proliferate on BC scaffolds [123].

In the work of Zhang et al. [124], the biocompatibility of BC as a scaffold for corneal stroma replacement was investigated using rabbit corneal epithelial and stroma cells cultured on $\mathrm{BC}$; the in vivo test confirmed the optical transparency in 3 month study, elucidating the $\mathrm{BC}$ potential in this area. 
Vascular grafts. Because of its good mechanical strength (a burst pressure of up to $880 \mathrm{mmHg}$ ) and blood compatibility, BC was used also for artificial tubes, which can be used as a potential replacement of small $(4 \mathrm{~mm})$ or large $(6 \mathrm{~mm})$ vascular grafts. Commercial product BASYC ${ }^{\circledR}$ was developed in tubular form directly during cultivation with the aim of developing biomaterials that can be used as coatings in experimental micronerve surgery and as artificial blood vessel interplants with an inner diameter of about $1 \mathrm{~mm}$, Ref. [125]. In addition to artificial blood vessels, BASYC ${ }^{\circledR}$ alone or loaded with a neuroregenerative drug has also shown promising results regarding tissue innervation in animal models after neurosurgical interventions.

In order to improve compliance of BC tubes for use as vascular grafts, poly (vinyl alcohol) (PVA) was introduced into the BC tubes, improving mechanical properties and water permeability. Ref. [126] The BC/PVA composite demonstrate good hemocompatibility with low platelet and factor XII activation and as such is a candidate for cardiac prostheses, Ref. [127]. BC/heparin composite as a mimetic of the natural ECM has been proposed to improve the blood compatibility and regenerative capacity of $\mathrm{BC}$. In the work of Wang et al. [128], a BC-chitosan/heparin composite was prepared and MC3T3-E1 cells were seeded on the obtained samples to test cell compatibility. The 3-(4,5-dimethylthiazol-2-yl)-2,5-diphenyltetrazolium bromide results showed that the BC-chitosan/heparin composites were suitable for cell proliferation and ingrowth.

Biosensors. Derikvand et al. [129] elaborated a versatile, chemo-enzymatic approach for activation of BC by simple copper (I)-catalysed azide-alkyne cycloaddition 'click chemistry' to develop new fluorogen esterase sensors. The facile aqueous modification was identified to facilitate wide applicability to cellulose papers, gauze and hydrogels. Linking the released fluorophore to the cellulose surface prevents signal degradation, allowing highly sensitive and simple visualisation (Figure 7a).

Group of Lv et al. [130] developed a self-powered biosensor using a glucose oxidase-based bioanode and a laccase-based biocathode decorated with multi-walled carbon nanotubes of carboxyl groups and a BC electrode modified with gold nanoparticles (Figure 7b). Experimental results showed that BC 3D network stability would be a very promising support for self-powered biosensors. Yao et al. [131] demonstrated the processing of colour tuneable luminescent macrofibers based on BC nanofibers loaded with CdTe quantum dots by wet spinning. The fluorescence intensity of the enzyme-modified microfibers was highly sensitive to the glucose concentration; their flexibility allows the conversion into a woven structure, which offers a great potential for the development of portable sensor devices.

The magnetic BC was evaluated as a magnetic hydrogel patch in the blood vessel, which was inserted with a stent to seal the neuro-endovascular cavity and normalise blood flow. A similar hydrogel was evaluated to improve the problems observed in the interaction of metallic biomaterials (replaced joints, metal plates and stents) and blood. These magnetic hydrogels and their derivatives, together with immobilised drugs, may be potential candidates for surface coating/printing of metallic implant surfaces, or applied to other drug delivery implants to minimise rejection and immune reactions [132].

The biphasic Janus hydrogels present conducting BC polymer hydrogels with double network that combine electro-activity with biocompatibility in the same device, Ref. [133]. They can act as an interface between biology and device, empowering creation of implantable devices for personalised and regenerative medicine. Electroactive hydrogels were prepared using $\mathrm{BC}$ and conductive polymer deposited on the surface of the $\mathrm{BC}$ hydrogel. The electrical conductivity gives the composites the ability to react to voltage and current and the $\mathrm{BC}$ hydrogel layer provides good biocompatibility, biodegradability, bio adhesion and mass transport properties. Such a system could enable selective biological functions such as molecular recognition and specific catalysis as well as the study of the complex genetic and molecular mechanisms. 


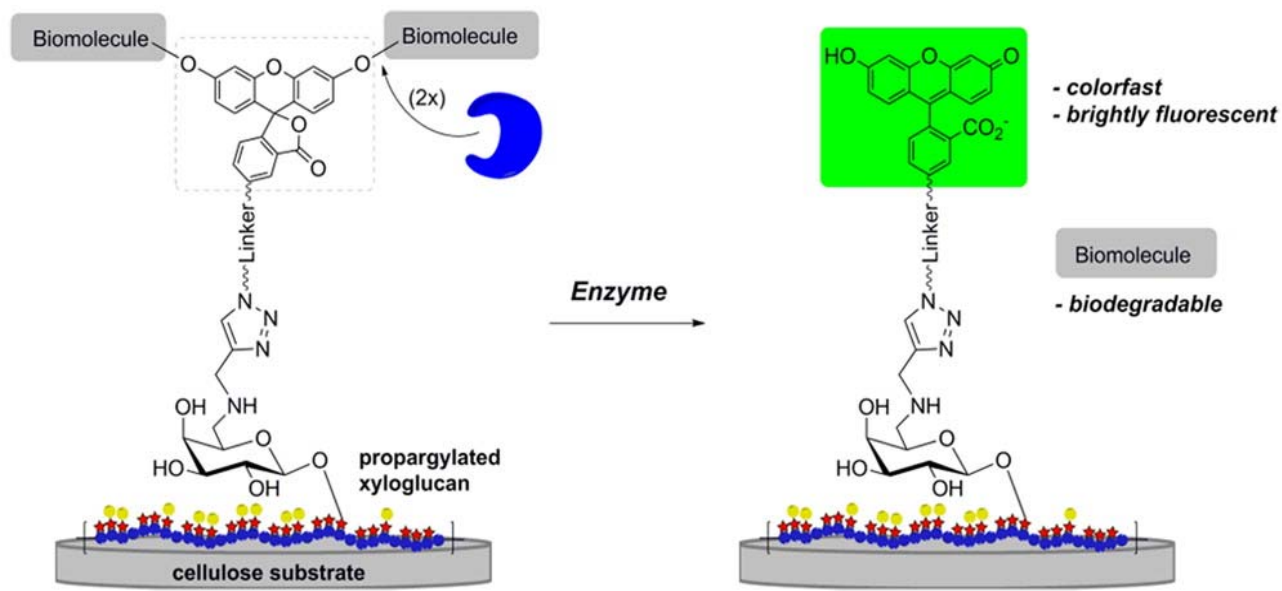

(a)

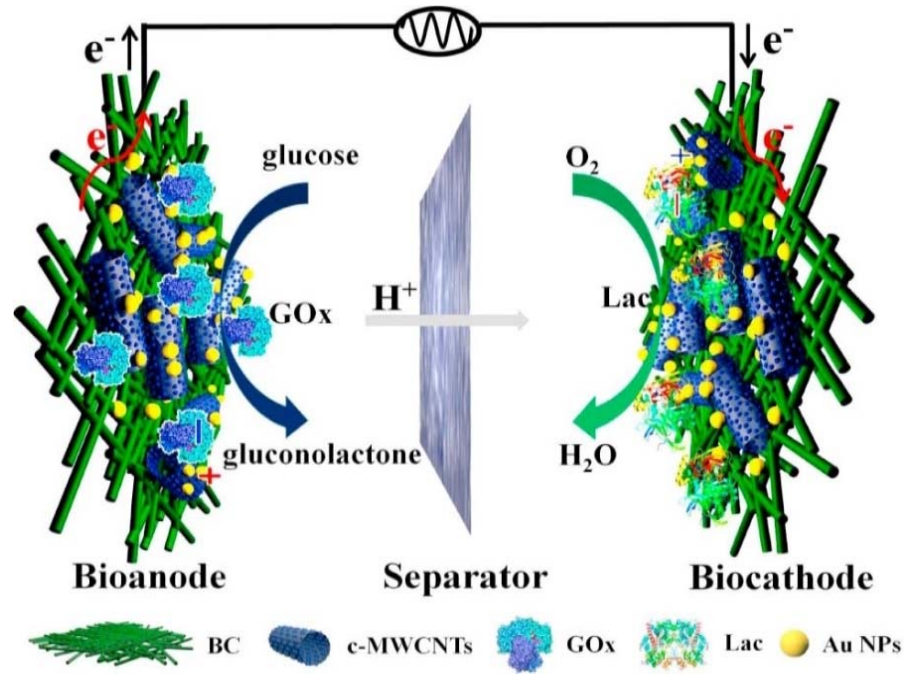

(b)

Figure 7. BC included into (a) esterase biosensor and (b) glucose oxidase biosensor. Reprinted with permission from (a) [129] and (b) [130]. Copyright (2016) American Chemical Society and (2018) Elsevier.

Artificial kidneys and dialysis. BC-graphen oxide (GO) composite hydrogels with excellent water stability, tensile strength, as well as improved toughness and discrepant permeation properties for various inorganic/organic ions of different sizes are presented by work of Shi et al. Ref. [134]. Composite membrane demonstrate capacity for very fast ions separation, opening up applications such as artificial kidneys and dialysis, which require precise separation of large and small molecules/ions.

Photodynamic therapy in cancer treatment. Conductive $\mathrm{BC} /$ polyaniline mixtures have received increasing attention in the scientific community not only for electronic applications but also for the development of novel electro-responsive drug delivery mechanisms, Ref. [135]. A physical dehydration method was used for the inclusion of the photosensitiser $\mathrm{C}_{60}$, which is used for photodynamic therapy in cancer treatment, successfully incorporating nanoparticles and distributing them evenly in the hyperfine BC network (Figure 8) [136]. 


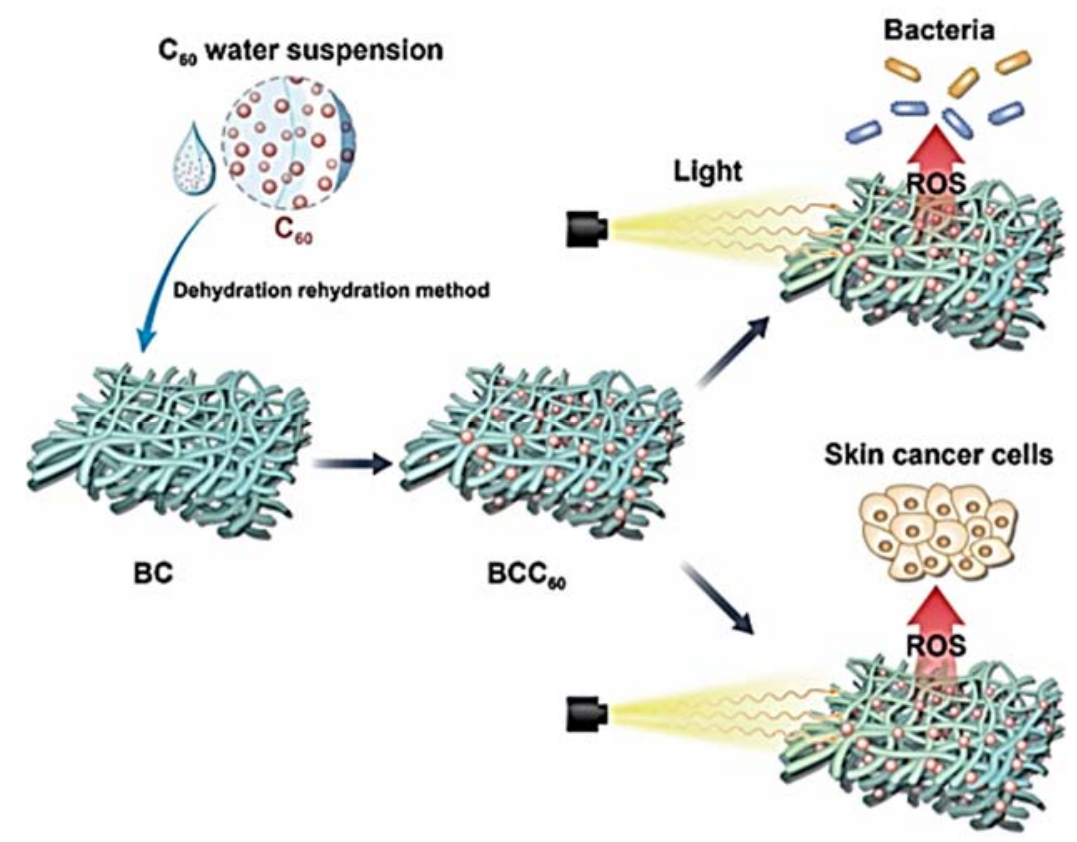

Figure 8. Physical de-hydration method for inclusion of photosensitiser $\mathrm{C}_{60}$ in $\mathrm{BC}$ for photodynamic therapy in cancer treatment. Reprinted with permission from [136]. Copyright (2018) The Royal Society of Chemistry.

\section{BC Prospects and Challenges}

The $\mathrm{BC}$ is fully in line with the principles of green chemistry, which fits well with the objectives of the circular economy, which include the minimization and reuse of waste as a raw material, and points out the importance of increasing research efforts for $\mathrm{BC}$ production and adapting to high-value markets such as the medical market. As a high-purity biological nonwoven, $\mathrm{BC}$ has gained interest in the medical field for more than 30 years, where it is used as a simple biotextile for bandaging to advanced skin replacement, hemostatic and dental membrane, material for artificial blood vessels, covering in nerve surgery, dura mater prostheses, arterial stent coating, cartilage and bone implants [8].

Since the first documented use of BC in biomedicine by a Brazilian company in 1986, which discussed the applications of Biofill ${ }^{\circledR}$ as skin replacement for burns and ulcers, extensive studies have been conducted on $\mathrm{BC}$ and its full application potential in tissue engineering has been gradually realised. $\mathrm{BC}$ composites go far beyond their original form $(\mathrm{BC})$ and are developing into advanced technological solutions for applications ranging from drug delivery to tissue engineering. Through compounding, surface modifications or simple mixing with other components, the inertness of the $\mathrm{BC}$ is improved, thus increasing its medical potential. The growing interest in BC composites offers great potential for improving the current production of biomedical materials for future regenerative medicine for the diagnosis and cure of various diseases. Although $\mathrm{BC}$ is considered biocompatible and non-toxic, the final composites and their degradation products need to be carefully examined, especially in translational research where strict regulations must be strictly adhered to ensure human health and safety.

Funding: Research core program group for Textile Chemistry No. P2-0118, and project BI-HR/20-21-00, financed by the Slovenian Research Agency (ARRS).

Conflicts of Interest: The author declare no conflict of interest.

\section{References}

1. Moradali, M.F.; Rehm, B.H.A. Bacterial biopolymers: From pathogenesis to advanced materials. Nat. Rev. Microbiol. 2020, 18, 195-210. [CrossRef] [PubMed] 
2. Tayeb, A.; Amini, E.; Ghasemi, S.; Tajvidi, M. Cellulose Nanomaterials-Binding Properties and Applications: A Review. Molecules 2018, 23, 2684. [CrossRef] [PubMed]

3. Abol-Fotouh, D.; Hassan, M.A.; Shokry, H.; Roig, A.; Azab, M.S.; Kashyout, A.E.H.B. Bacterial nanocellulose from agro-industrial wastes: Low-cost and enhanced production by Komagataeibacter saccharivorans MD1. Sci. Rep. 2020, 10, 1-14. [CrossRef] [PubMed]

4. Vigentini, I.; Fabrizio, V.; Dellacà, F.; Rossi, S.; Azario, I.; Mondin, C.; Benaglia, M.; Foschino, R. Set-Up of Bacterial Cellulose Production From the Genus Komagataeibacter and Its Use in a Gluten-Free Bakery Product as a Case Study. Front. Microbiol. 2019, 10, 1953. [CrossRef] [PubMed]

5. Trček, J.; Barja, F. Updates on quick identification of acetic acid bacteria with a focus on the 16S-23S rRNA gene internal transcribed spacer and the analysis of cell proteins by MALDI-TOF mass spectrometry. Int. J. Food Microbiol. 2015, 196, 137-144. [CrossRef]

6. Slapšak, N.; Cleenwerck, I.; De Vos, P.; Trček, J. Gluconacetobacter maltaceti sp. nov., a novel vinegar producing acetic acid bacterium. Syst. Appl. Microbiol. 2013, 36, 17-21. [CrossRef]

7. Brown, R.M. The biosynthesis of cellulose. Top. Catal. 1987, 1, 345-351. [CrossRef]

8. Gorgieva, S.; Trček, J. Bacterial cellulose: Production, modification and perspectives in biomedical applications. Nanomaterials 2019, 9, 1352. [CrossRef]

9. Maleš, L.; Fakin, D.; Bračič, M.; Gorgieva, S. Efficiency of Differently Processed Membranes Based on Cellulose as Cationic Dye Adsorbents. Nanomaterials 2020, 10, 642. [CrossRef]

10. Lv, X.; Yang, J.; Feng, C.; Li, Z.; Chen, S.; Xie, M.; Huang, J.; Li, H.; Wang, H.; Xu, Y. Bacterial Cellulose-Based Biomimetic Nanofibrous Scaffold with Muscle Cells for Hollow Organ Tissue Engineering. ACS Biomater. Sci. Eng. 2016, 2, 19-29. [CrossRef]

11. Dufresne, A. Nanocellulose: From Nature to High Performance Tailored Materials; Walter de Gruyter: Berlin, Germany, 2012; ISBN 3110254603.

12. Esa, F.; Tasirin, S.M.; Rahman, N.A. Overview of Bacterial Cellulose Production and Application. Agric. Agric. Sci. Procedia 2014, 2, 113-119. [CrossRef]

13. Fijałkowski, K.; Zywicka, A.; Drozd, R.; Niemczyk, A.; Junka, A.F.; Peitler, D.; Kordas, M.; Konopacki, M.; Szymczyk, P.; Fray, M.E.; et al. Modification of bacterial cellulose through exposure to the rotating magnetic field. Carbohydr. Polym. 2015, 133, 52-60. [CrossRef] [PubMed]

14. Gao, M.; Li, J.; Bao, Z.; Hu, M.; Nian, R.; Feng, D.; An, D.; Li, X.; Xian, M.; Zhang, H. A natural in situ fabrication method of functional bacterial cellulose using a microorganism. Nat. Commun. 2019, 10, 437. [CrossRef]

15. Sun, B.; Zhang, L.; Wei, F.; AL-Ammari, A.; Xu, X.; Li, W.; Chen, C.; Lin, J.; Zhang, H.; Sun, D. In situ structural modification of bacterial cellulose by sodium fluoride. Carbohydr. Polym. 2020, 231, 115765. [CrossRef] [PubMed]

16. Tischer, P.C.S.F.; Sierakowski, M.R.; Westfahl, H.; Tischer, C.A. Nanostructural reorganization of bacterial cellulose by ultrasonic treatment. Biomacromolecules 2010, 11, 1217-1224. [CrossRef] [PubMed]

17. Paximada, P.; Dimitrakopoulou, E.A.; Tsouko, E.; Koutinas, A.A.; Fasseas, C.; Mandala, I.G. Structural modification of bacterial cellulose fibrils under ultrasonic irradiation. Carbohydr. Polym. 2016, 150, 5-12. [CrossRef]

18. Darwis, D.; Khusniya, T.; Hardiningsih, L.; Nurlidar, F.; Winarno, H. In-vitro Degradation Behaviour of Irradiated Bacterial Cellulose Membrane. Atom Indones. 2013, 38, 78. [CrossRef]

19. Czaja, W.K.; Young, D.J.; Kawecki, M.; Brown, R.M. The future prospects of microbial cellulose in biomedical applications. Biomacromolecules 2007, 8, 1-12. [CrossRef]

20. Gorgieva, S.; Hribernik, S. Microstructured and Degradable Bacterial Cellulose-Gelatin Composite Membranes: Mineralization Aspects and Biomedical Relevance. Nanomaterials 2019, 9, 303. [CrossRef]

21. Peng, S.; Zheng, Y.; Wu, J.; Wu, Y.; Ma, Y.; Song, W.; Xi, T. Preparation and characterization of degradable oxidized bacterial cellulose reacted with nitrogen dioxide. Polym. Bull. 2012, 68, 415-423. [CrossRef]

22. Hu, Y.; Catchmark, J.M. Integration of cellulases into bacterial cellulose: Toward bioabsorbable cellulose composites. J. Biomed. Mater. Res. Part B Appl. Biomater. 2011, 97 B, 114-123. [CrossRef]

23. Foresti, M.L.; Vázquez, A.; Boury, B. Applications of bacterial cellulose as precursor of carbon and composites with metal oxide, metal sulfide and metal nanoparticles: A review of recent advances. Carbohydr. Polym. 2017, 157, 447-467. [CrossRef] [PubMed] 
24. Choi, S.M.; Shin, E.J. The Nanofication and Functionalization of Bacterial Cellulose and Its Applications. Nanomaterials 2020, 10, 406. [CrossRef] [PubMed]

25. Singhsa, P.; Narain, R.; Manuspiya, H. Bacterial Cellulose Nanocrystals (BCNC) Preparation and Characterization from Three Bacterial Cellulose Sources and Development of Functionalized BCNCs as Nucleic Acid Delivery Systems. ACS Appl. Nano Mater. 2018, 1, 209-221. [CrossRef]

26. Woehl, M.A.; Ono, L.; Riegel Vidotti, I.C.; Wypych, F.; Schreiner, W.H.; Sierakowski, M.R. Bioactive nanocomposites of bacterial cellulose and natural hydrocolloids. J. Mater. Chem. B 2014, 2, 7034-7044. [CrossRef] [PubMed]

27. Noh, Y.K.; Dos Santos Da Costa, A.; Park, Y.S.; Du, P.; Kim, I.H.; Park, K. Fabrication of bacterial cellulosecollagen composite scaffolds and their osteogenic effect on human mesenchymal stem cells. Carbohydr. Polym. 2019, 219, 210-218. [CrossRef] [PubMed]

28. Zhang, W.; Wang, X.C.; Li, X.Y.; Zhang, L.L.; Jiang, F. A 3D porous microsphere with multistage structure and component based on bacterial cellulose and collagen for bone tissue engineering. Carbohydr. Polym. 2020, 236, 116043-116051. [CrossRef]

29. Osorio, M.; Ortiz, I.; Gañán, P.; Naranjo, T.; Zuluaga, R.; van Kooten, T.G.; Castro, C. Novel surface modification of three-dimensional bacterial nanocellulose with cell-derived adhesion proteins for soft tissue engineering. Mater. Sci. Eng. C 2019, 100, 697-705. [CrossRef]

30. Lin, W.-C.; Lien, C.-C.; Yeh, H.-J.; Yu, C.-M.; Hsu, S. Bacterial cellulose and bacterial cellulose-chitosan membranes for wound dressing applications. Carbohydr. Polym. 2013, 94, 603-611. [CrossRef]

31. Yuan, H.; Chen, L.; Hong, F.F. A Biodegradable Antibacterial Nanocomposite Based on Oxidized Bacterial Nanocellulose for Rapid Hemostasis and Wound Healing. ACS Appl. Mater. Interfaces 2020, 12, 3382-3392. [CrossRef]

32. Yadav, V.; Paniliatis, B.J.; Shi, H.; Lee, K.; Cebe, P.; Kaplan, D.L. Novel in vivo-degradable cellulose-chitin copolymer from metabolically engineered gluconacetobacter xylinus. Appl. Environ. Microbiol. 2010, 76, 6257-6265. [CrossRef] [PubMed]

33. De Lima Fontes, M.; Meneguin, A.B.; Tercjak, A.; Gutierrez, J.; Cury, B.S.F.; dos Santos, A.M.; Ribeiro, S.J.L.; Barud, H.S. Effect of in situ modification of bacterial cellulose with carboxymethylcellulose on its nano/microstructure and methotrexate release properties. Carbohydr. Polym. 2018, 179, 126-134. [CrossRef] [PubMed]

34. Wei, J.; Wang, B.; Li, Z.; Wu, Z.; Zhang, M.; Sheng, N.; Liang, Q.; Wang, H.; Chen, S. A 3D-printable TEMPO-oxidized bacterial cellulose/alginate hydrogel with enhanced stability via nanoclay incorporation. Carbohydr. Polym. 2020, 238, 116207-116217. [CrossRef] [PubMed]

35. Lopes, T.D.; Riegel-Vidotti, I.C.; Grein, A.; Tischer, C.A.; de Sousa Faria-Tischer, P.C. Bacterial cellulose and hyaluronic acid hybrid membranes: Production and characterization. Int. J. Biol. Macromol. 2014, 67, 401-408. [CrossRef]

36. Jia, Y.; Huo, M.; Huang, H.; Fu, W.; Wang, Y.; Zhang, J.; Jia, S. Preparation and characterization of bacterial cellulose/hyaluronic acid composites. Proc. Inst. Mech. Eng. Part N J. Nanoeng. Nanosyst. 2015, 229, 41-48. [CrossRef]

37. De Olyveira, G.M.; dos Santos, M.L.; Daltro, P.B.; Basmaji, P.; de Cerqueira Daltro, G.; Guastaldi, A.C. Bacterial cellulose/chondroitin sulfate for dental materials scaffolds. J. Biomater. Tissue Eng. 2014, 4, 150-154. [CrossRef]

38. Azarniya, A.; Tamjid, E.; Eslahi, N.; Simchi, A. Modification of bacterial cellulose/keratin nanofibrous mats by a tragacanth gum-conjugated hydrogel for wound healing. Int. J. Biol. Macromol. 2019, 134, 280-289. [CrossRef]

39. Luo, H.; Ao, H.; Li, G.; Li, W.; Xiong, G.; Zhu, Y.; Wan, Y. Bacterial cellulose/graphene oxide nanocomposite as a novel drug delivery system. Curr. Appl. Phys. 2017, 17, 249-254. [CrossRef]

40. Shao, W.; Liu, H.; Liu, X.; Wang, S.; Zhang, R. Anti-bacterial performances and biocompatibility of bacterial cellulose/graphene oxide composites. RSC Adv. 2015, 5, 4795-4803. [CrossRef]

41. Si, H.; Luo, H.; Xiong, G.; Yang, Z.; Raman, S.R.; Guo, R.; Wan, Y. One-Step In Situ Biosynthesis of Graphene Oxide-Bacterial Cellulose Nanocomposite Hydrogels. Macromol. Rapid Commun. 2014, 35, 1706-1711. [CrossRef] 
42. Khalid, A.; Ullah, H.; Ul-Islam, M.; Khan, R.; Khan, S.; Ahmad, F.; Khan, T.; Wahid, F. Bacterial cellulose-TiO2 nanocomposites promote healing and tissue regeneration in burn mice model. RSC Adv. 2017, 7, 47662-47668. [CrossRef]

43. Pal, S.; Nisi, R.; Stoppa, M.; Licciulli, A. Silver-Functionalized Bacterial Cellulose as Antibacterial Membrane for Wound-Healing Applications. ACS Omega 2017, 2, 3632-3639. [CrossRef] [PubMed]

44. Duarte, E.B.; das Chagas, B.S.; Andrade, F.K.; Brígida, A.I.S.; Borges, M.F.; Muniz, C.R.; Souza Filho, M.d.S.M.; Morais, J.P.S.; Feitosa, J.P.A.; Rosa, M.F. Production of hydroxyapatite-bacterial cellulose nanocomposites from agroindustrial wastes. Cellulose 2015, 22, 3177-3187. [CrossRef]

45. Pigossi, S.C.; de Oliveira, G.J.P.L.; Finoti, L.S.; Nepomuceno, R.; Spolidorio, L.C.; Rossa, C.; Ribeiro, S.J.L.; Saska, S.; Scarel-Caminaga, R.M. Bacterial cellulose-hydroxyapatite composites with osteogenic growth peptide (OGP) or pentapeptide OGP on bone regeneration in critical-size calvarial defect model. J. Biomed. Mater. Res. Part A 2015, 103, 3397-3406. [CrossRef]

46. Basu, P.; Saha, N.; Alexandrova, R.; Saha, P. Calcium phosphate incorporated bacterial cellulosepolyvinylpyrrolidone based hydrogel scaffold: Structural property and cell viability study for bone regeneration application. Polymers (Basel) 2019, 11, 1821. [CrossRef]

47. Busuioc, C.; Ghitulica, C.D.; Stoica, A.; Stroescu, M.; Voicu, G.; Ionita, V.; Averous, L.; Jinga, S.I. Calcium phosphates grown on bacterial cellulose template. Ceram. Int. 2018, 44, 9433-9441. [CrossRef]

48. Ul-Islam, M.; Khan, T.; Park, J.K. Nanoreinforced bacterial cellulose-montmorillonite composites for biomedical applications. Carbohydr. Polym. 2012, 89, 1189-1197. [CrossRef]

49. Khodamoradi, N.; Babaeipour, V.; Sirousazar, M. Bacterial cellulose/montmorillonite bionanocomposites prepared by immersion and in-situ methods: Structural, mechanical, thermal, swelling and dehydration properties. Cellulose 2019, 26, 7847-7861. [CrossRef]

50. Velichko, E.V.; Buyanov, A.L.; Saprykina, N.N.; Chetverikov, Y.O.; Duif, C.P.; Bouwman, W.G.; Smyslov, R.Y. High-strength bacterial cellulose-polyacrylamide hydrogels: Mesostructure anisotropy as studied by spin-echo small-angle neutron scattering and cryo-SEM. Eur. Polym. J. 2017, 88, 269-279. [CrossRef]

51. Yuan, N.; Xu, L.; Zhang, L.; Ye, H.; Zhao, J.; Liu, Z.; Rong, J. Superior hybrid hydrogels of polyacrylamide enhanced by bacterial cellulose nanofiber clusters. Mater. Sci. Eng. C 2016, 67, 221-230. [CrossRef]

52. Rapid Synthesis of Superabsorbent Smart-Swelling Bacterial Cellulose/Acrylamide-Based Hydrogels for Drug Delivery. Available online: https://www.hindawi.com/journals/ijps/2013/905471/ (accessed on 4 May 2020).

53. Foong, C.Y.; Hamzah, M.S.A.; Razak, S.I.A.; Saidin, S.; Nayan, N.H.M. Influence of Poly(lactic acid) Layer on the Physical and Antibacterial Properties of Dry Bacterial Cellulose Sheet for Potential Acute Wound Healing Materials. Fibers Polym. 2018, 19, 263-271. [CrossRef]

54. Leitão, A.F.; Silva, J.P.; Dourado, F.; Gama, M. Production and characterization of a new bacterial cellulose/poly(Vinyl Alcohol) nanocomposite. Materials (Basel). 2013, 6, 1956-1966. [CrossRef] [PubMed]

55. Mohamad, N.; Loh, E.Y.X.; Fauzi, M.B.; Ng, M.H.; Mohd Amin, M.C.I. In vivo evaluation of bacterial cellulose/acrylic acid wound dressing hydrogel containing keratinocytes and fibroblasts for burn wounds. Drug Deliv. Transl. Res. 2019, 9, 444-452. [CrossRef] [PubMed]

56. Black, J. Biological Performance of Materials: Fundamentals of Biocompatibility; CRC Taylor \& Francis: Boca Raton, FL, USA, 2006; ISBN 0849339596.

57. Petersen, N.; Gatenholm, P. Bacterial cellulose-based materials and medical devices: Current state and perspectives. Appl. Microbiol. Biotechnol. 2011, 91, 1277-1286. [CrossRef]

58. Guidance for Industry: Pyrogen and Endotoxins Testing: Questions and Answers | FDA. Available online: https://www.fda.gov/regulatory-information/search-fda-guidance-documents/guidance-industrypyrogen-and-endotoxins-testing-questions-and-answers (accessed on 13 April 2020).

59. Andersson, J.; Stenhamre, H.; Bäckdahl, H.; Gatenholm, P. Behavior of human chondrocytes in engineered porous bacterial cellulose scaffolds. J. Biomed. Mater. Res. Part A 2010, 94, 1124-1132. [CrossRef]

60. Taokaew, S.; Phisalaphong, M.; Newby, B.M.Z. Modification of bacterial cellulose with organosilanes to improve attachment and spreading of human fibroblasts. Cellulose 2015, 22, 2311-2324. [CrossRef]

61. Sanchavanakit, N.; Sangrungraungroj, W.; Kaomongkolgit, R.; Banaprasert, T.; Pavasant, P.; Phisalaphong, M. Growth of Human Keratinocytes and Fibroblasts on Bacterial Cellulose Film. Biotechnol. Prog. 2006, 22, 1194-1199. [CrossRef] 
62. Hu, Y.; Catchmark, J.M.; Vogler, E.A. Factors Impacting the Formation of Sphere-Like Bacterial Cellulose Particles and Their Biocompatibility for Human Osteoblast Growth. Biomacromolecules 2013, 14, 3444-3452. [CrossRef]

63. Feil, G.; Horres, R.; Schulte, J.; Mack, A.F.; Petzoldt, S.; Arnold, C.; Meng, C.; Jost, L.; Boxleitner, J.; Kiessling-Wolf, N.; et al. Bacterial cellulose shifts transcriptome and proteome of cultured endothelial cells towards native differentiation. Mol. Cell. Proteomics 2017, 16, 1563-1577. [CrossRef]

64. Vadaye Kheiry, E.; Parivar, K.; Baharara, J.; Fazly Bazzaz, B.S.; Iranbakhsh, A. The osteogenesis of bacterial cellulose scaffold loaded with fisetin. Iran. J. Basic Med. Sci. 2018, 21, 965-971.

65. Souza, C.M.C.O.; Mesquita, L.A.F.; Souza, D.; Irioda, A.C.; Francisco, J.C.; Souza, C.F.; Guarita-Souza, L.C.; Sierakowski, M.-R.; Carvalho, K.A.T. Regeneration of Skin Tissue Promoted by Mesenchymal Stem Cells Seeded in Nanostructured Membrane. Transplant. Proc. 2014, 46, 1882-1886. [CrossRef] [PubMed]

66. Vielreicher, M.; Kralisch, D.; Völkl, S.; Sternal, F.; Arkudas, A.; Friedrich, O. Bacterial nanocellulose stimulates mesenchymal stem cell expansion and formation of stable collagen-I networks as a novel biomaterial in tissue engineering. Sci. Rep. 2018, 8, 1-14. [CrossRef] [PubMed]

67. Acasigua, G.; Olyveira, G.; Costa, L.; Braghirolli, D.; Fossati, A.; Guastaldi, A.; Pranke, P.; Daltro, G.; Basmaji, P. Novel Chemically Modified Bacterial Cellulose Nanocomposite as Potential Biomaterial for Stem Cell Therapy Applications. Curr. Stem Cell Res. Ther. 2014, 9, 117-123. [CrossRef] [PubMed]

68. Bäckdahl, H.; Helenius, G.; Bodin, A.; Nannmark, U.; Johansson, B.R.; Risberg, B.; Gatenholm, P. Mechanical properties of bacterial cellulose and interactions with smooth muscle cells. Biomaterials 2006, 27, 2141-2149. [CrossRef] [PubMed]

69. Fu, L.; Zhou, P.; Zhang, S.; Yang, G. Evaluation of bacterial nanocellulose-based uniform wound dressing for large area skin transplantation. Mater. Sci. Eng. C 2013, 33, 2995-3000. [CrossRef]

70. Pértile, R.A.N.; Moreira, S.; Gil Da Costa, R.M.; Correia, A.; Guardão, L.; Gartner, F.; Vilanova, M.; Gama, M. Bacterial cellulose: Long-term biocompatibility studies. J. Biomater. Sci. Polym. Ed. 2012, 23, 1339-1354. [CrossRef]

71. Sulaeva, I.; Henniges, U.; Rosenau, T.; Potthast, A. Bacterial cellulose as a material for wound treatment: Properties and modifications: A review. Biotechnol. Adv. 2015, 33, 1547-1571. [CrossRef]

72. Kucińska-Lipka, J.; Gubanska, I.; Janik, H. Bacterial cellulose in the field of wound healing and regenerative medicine of skin: Recent trends and future prospectives. Polym. Bull. 2015, 72, 2399-2419. [CrossRef]

73. Anton-Sales, I.; Beekmann, U.; Laromaine, A.; Roig, A.; Kralisch, D. Opportunities of Bacterial Cellulose to Treat Epithelial Tissues. Curr. Drug Targets 2018, 20, 808-822. [CrossRef]

74. Li, Y.; Wang, S.; Huang, R.; Huang, Z.; Hu, B.; Zheng, W.; Yang, G.; Jiang, X. Evaluation of the Effect of the Structure of Bacterial Cellulose on Full Thickness Skin Wound Repair on a Microfluidic Chip. Biomacromolecules 2015, 16, 780-789. [CrossRef]

75. Gonzalez, A.C.D.O.; Andrade, Z.D.A.; Costa, T.F.; Medrado, A.R.A.P. Wound healing-A literature review. An. Bras. Dermatol. 2016, 91, 614-620. [CrossRef] [PubMed]

76. Velnar, T.; Bailey, T.; Smrkolj, V. The wound healing process: An overview of the cellular and molecular mechanisms. J. Int. Med. Res. 2009, 37, 1528-1542. [CrossRef] [PubMed]

77. Portela, R.; Leal, C.R.; Almeida, P.L.; Sobral, R.G. Bacterial cellulose: A versatile biopolymer for wound dressing applications. Microb. Biotechnol. 2019, 12, 586-610. [CrossRef] [PubMed]

78. De Sousa Moraes, P.R.F.; Saska, S.; Barud, H.; De Lima, L.R.; Da Conceicao Amaro Martins, V.; De Guzzi Plepis, A.M.; Ribeiro, S.J.L.; Gaspar, A.M.M. Bacterial cellulose/collagen hydrogel for wound healing. Mater. Res. 2016, 19, 106-116. [CrossRef]

79. Khan, S.; Ul-Islam, M.; Ikram, M.; Islam, S.U.; Ullah, M.W.; Israr, M.; Jang, J.H.; Yoon, S.; Park, J.K. Preparation and structural characterization of surface modified microporous bacterial cellulose scaffolds: A potential material for skin regeneration applications in vitro and in vivo. Int. J. Biol. Macromol. 2018, 117, 1200-1210. [CrossRef]

80. Meng, E.; Chen, C.L.; Liu, C.C.; Liu, C.C.; Chang, S.J.; Cherng, J.H.; Wang, H.H.; Wu, S.T. Bioapplications of bacterial cellulose polymers conjugated with resveratrol for epithelial defect regeneration. Polymers (Basel) 2019, 11, 1048. [CrossRef]

81. Volova, T.G.; Shumilova, A.A.; Nikolaeva, E.D.; Kirichenko, A.K.; Shishatskaya, E.I. Biotechnological wound dressings based on bacterial cellulose and degradable copolymer $\mathrm{P}(3 \mathrm{HB} / 4 \mathrm{HB})$. Int. J. Biol. Macromol. 2019, 131, 230-240. [CrossRef] 
82. Khamrai, M.; Banerjee, S.L.; Paul, S.; Samanta, S.; Kundu, P.P. Curcumin entrapped gelatin/ionically modified bacterial cellulose based self-healable hydrogel film: An eco-friendly sustainable synthesis method of wound healing patch. Int. J. Biol. Macromol. 2019, 122, 940-953. [CrossRef]

83. Suprasorb X+PHMB - L\&R Medical (Lohmann \& Rauscher UK, formerly Activa Healthcare). Available online: https://lohmann-rauscher.co.uk/woundcare/suprasorb/suprasorb-x-phmb (accessed on 5 May 2020).

84. Membracel-Membrana Regeneradora Porosa / Vuelo PharmaVuelo Pharma. Available online: https://www. vuelopharma.com/en/produto/membracel-membrana-regeneradora-porosa/ (accessed on 5 May 2020).

85. Delli Santi, G.; Borgognone, A. The use of Epiprotect $($, an advanced wound dressing, to heal paediatric patients with burns: A pilot study. Burn. Open 2019, 3, 103-107. [CrossRef]

86. Butchosa, N.; Brown, C.; Larsson, P.T.; Berglund, L.A.; Bulone, V.; Zhou, Q. Nanocomposites of bacterial cellulose nanofibers and chitin nanocrystals: Fabrication, characterization and bactericidal activity. Green Chem. 2013, 15, 3404. [CrossRef]

87. Laçin, N.T. Development of biodegradable antibacterial cellulose based hydrogel membranes for wound healing. Int. J. Biol. Macromol. 2014, 67, 22-27. [CrossRef] [PubMed]

88. Ye, S.; Jiang, L.; Wu, J.; Su, C.; Huang, C.; Liu, X.; Shao, W. Flexible Amoxicillin-Grafted Bacterial Cellulose Sponges for Wound Dressing: In Vitro and in Vivo Evaluation. ACS Appl. Mater. Interfaces 2018, 10, 5862-5870. [CrossRef]

89. Rouabhia, M.; Asselin, J.; Tazi, N.; Messaddeq, Y.; Levinson, D.; Zhang, Z. Production of Biocompatible and Antimicrobial Bacterial Cellulose Polymers Functionalized by RGDC Grafting Groups and Gentamicin. ACS Appl. Mater. Interfaces 2014, 6, 1439-1446. [CrossRef] [PubMed]

90. Junka, A.; Bartoszewicz, M.; Dziadas, M.; Szymczyk, P.; Dydak, K.; Żywicka, A.; Owczarek, A.; Bil-Lula, I.; Czajkowska, J.; Fijałkowski, K. Application of bacterial cellulose experimental dressings saturated with gentamycin for management of bone biofilm in vitro and ex vivo. J. Biomed. Mater. Res. Part B Appl. Biomater. 2020, 108, 30-37. [CrossRef] [PubMed]

91. Fernandes, S.C.M.; Sadocco, P.; Alonso-Varona, A.; Palomares, T.; Eceiza, A.; Silvestre, A.J.D.; Mondragon, I.; Freire, C.S.R. Bioinspired antimicrobial and biocompatible bacterial cellulose membranes obtained by surface functionalization with aminoalkyl groups. ACS Appl. Mater. Interfaces 2013, 5, 3290-3297. [CrossRef] [PubMed]

92. Hou, A.; Zhou, M.; Wang, X. Preparation and characterization of durable antibacterial cellulose biomaterials modified with triazine derivatives. Carbohydr. Polym. 2009, 75, 328-332. [CrossRef]

93. Wang, T.; Xu, L.; Shen, H.; Cao, X.; Wei, Q.; Ghiladi, R.A.; Wang, Q. Photoinactivation of bacteria by hypocrellin- grafted bacterial cellulose. Cellulose 2020, 27, 991-1007. [CrossRef]

94. Vismara, E.; Bernardi, A.; Bongio, C.; Farè, S.; Pappalardo, S.; Serafini, A.; Pollegioni, L.; Rosini, E.; Torri, G. Bacterial nanocellulose and its surface modification by glycidyl methacrylate and ethylene glycol dimethacrylate. Incorporation of vancomycin and ciprofloxacin. Nanomaterials 2019, 9, 1668-1690.

95. Maneerung, T.; Tokura, S.; Rujiravanit, R. Impregnation of silver nanoparticles into bacterial cellulose for antimicrobial wound dressing. Carbohydr. Polym. 2008, 72, 43-51. [CrossRef]

96. Wichai, S.; Chuysinuan, P.; Chaiarwut, S.; Ekabutr, P.; Supaphol, P. Development of bacterial cellulose/alginate/ chitosan composites incorporating copper (II) sulfate as an antibacterial wound dressing. J. Drug Deliv. Sci. Technol. 2019, 51, 662-671. [CrossRef]

97. Ataide, J.A.; De Carvalho, N.M.; Rebelo, M.D.A.; Chaud, M.V.; Grotto, D.; Gerenutti, M.; Rai, M.; Mazzola, P.G.; Jozala, A.F. Bacterial Nanocellulose Loaded with Bromelain: Assessment of Antimicrobial, Antioxidant and Physical-Chemical Properties. Sci. Rep. 2017, 7, 1-9. [CrossRef] [PubMed]

98. Khamrai, M.; Banerjee, S.L.; Paul, S.; Ghosh, A.K.; Sarkar, P.; Kundu, P.P. A Mussel Mimetic, Bioadhesive, Antimicrobial Patch Based on Dopamine-Modified Bacterial Cellulose/rGO/Ag NPs: A Green Approach toward Wound-Healing Applications. ACS Sustain. Chem. Eng. 2019, 7, 12083-12097. [CrossRef]

99. Bayir, E.; Celtikoglu, M.M.; Sendemir, A. The use of bacterial cellulose as a basement membrane improves the plausibility of the static in vitro blood-brain barrier model. Int. J. Biol. Macromol. 2019, 126, 1002-1013. [CrossRef] [PubMed]

100. Weyell, P.; Beekmann, U.; Küpper, C.; Dederichs, M.; Thamm, J.; Fischer, D.; Kralisch, D. Tailor-made material characteristics of bacterial cellulose for drug delivery applications in dentistry. Carbohydr. Polym. 2019, 207, 1-10. [CrossRef] 
101. Jinga, S.I.; Voicu, G.; Stoica-Guzun, A.; Stroescu, M.; Grumezescu, A.M.; Bleotu, C. Biocellulose Nanowhiskers Cement Composites for Endodontic USE. Dig. J. Nanomater. Biostruct. 2014, 9, 543-550.

102. Voicu, G.; Jinga, S.I.; Drosu, B.G.; Busuioc, C. Improvement of silicate cement properties with bacterial cellulose powder addition for applications in dentistry. Carbohydr. Polym. 2017, 174, 160-170. [CrossRef]

103. Lechner, J.; Noumbissi, S.; von Baehr, V. Titanium implants and silent inflammation in jawbone-a critical interplay of dissolved titanium particles and cytokines TNF- $\alpha$ and RANTES/CCL5 on overall health? EPMA J. 2018, 9, 331-343. [CrossRef]

104. Abeer, M.M.; Mohd Amin, M.C.I.; Martin, C. A review of bacterial cellulose-based drug delivery systems: Their biochemistry, current approaches and future prospects. J. Pharm. Pharmacol. 2014, 66, 1047-1061. [CrossRef]

105. Zaborowska, M.; Bodin, A.; Bäckdahl, H.; Popp, J.; Goldstein, A.; Gatenholm, P. Microporous bacterial cellulose as a potential scaffold for bone regeneration. Acta Biomater. 2010, 6, 2540-2547. [CrossRef]

106. Andrade, F.K.; Morais, J.P.S.; Muniz, C.R.; Nascimento, J.H.O.; Vieira, R.S.; Gama, F.M.P.; Rosa, M.F. Stable microfluidized bacterial cellulose suspension. Cellulose 2019, 26, 5851-5864. [CrossRef]

107. Coelho, F.; Cavicchioli, M.; Specian, S.S.; Scarel-Caminaga, R.M.; Penteado, L.d.A.; Medeiros, A.I.d.; Ribeiro, S.J.d.L.; Capote, T.S.d.O. Bacterial cellulose membrane functionalized with hydroxiapatite and anti-bone morphogenetic protein 2: A promising material for bone regeneration. PLoS ONE 2019, 14, e0221286. [CrossRef] [PubMed]

108. Zhu, X.; Chen, T.; Feng, B.; Weng, J.; Duan, K.; Wang, J.; Lu, X. Biomimetic Bacterial Cellulose-Enhanced Double-Network Hydrogel with Excellent Mechanical Properties Applied for the Osteochondral Defect Repair. ACS Biomater. Sci. Eng. 2018, 4, 3534-3544. [CrossRef]

109. Martínez Ávila, H.; Feldmann, E.M.; Pleumeekers, M.M.; Nimeskern, L.; Kuo, W.; de Jong, W.C.; Schwarz, S.; Müller, R.; Hendriks, J.; Rotter, N.; et al. Novel bilayer bacterial nanocellulose scaffold supports neocartilage formation invitro and invivo. Biomaterials 2015, 44, 122-133. [CrossRef] [PubMed]

110. Shoseyov, O.; Kam, D.; Ben Shalom, T.; Shtein, Z.; Vinkler, S.; Posen, Y. Nanocellulose Composite Biomaterials in Industry and Medicine; Springer: Cham, Switzerland; Basel, Switzerland, 2019; pp. 693-784.

111. Badshah, M.; Ullah, H.; Khan, A.R.; Khan, S.; Park, J.K.; Khan, T. Surface modification and evaluation of bacterial cellulose for drug delivery. Int. J. Biol. Macromol. 2018, 113, 526-533. [CrossRef] [PubMed]

112. Narh, C.; Charles, F.; Mensah, A.; Qufu, W. Synthesis of highly stable bacterial cellulosic pocket for drug storage. Carbohydr. Polym. 2019, 206, 625-632. [CrossRef] [PubMed]

113. Juncu, G.; Stoica-Guzun, A.; Stroescu, M.; Isopencu, G.; Jinga, S.I. Drug release kinetics from carboxymethylcellulose-bacterial cellulose composite films. Int. J. Pharm. 2016, 510, 485-492. [CrossRef]

114. Ahmad, N.; Amin, M.C.I.M.; Mahali, S.M.; Ismail, I.; Chuang, V.T.G. Biocompatible and mucoadhesive bacterial cellulose-g-poly(acrylic acid) hydrogels for oral protein delivery. Mol. Pharm. 2014, 11, 4130-4142. [CrossRef]

115. Silva, N.H.C.S.; Mota, J.P.; Santos de Almeida, T.; Carvalho, J.P.F.; Silvestre, A.J.D.; Vilela, C.; Rosado, C.; Freire, C.S.R. Topical Drug Delivery Systems Based on Bacterial Nanocellulose: Accelerated Stability Testing. Int. J. Mol. Sci. 2020, 21, 1262. [CrossRef]

116. Cacicedo, M.L.; Islan, G.A.; Drachemberg, M.F.; Alvarez, V.A.; Bartel, L.C.; Bolzán, A.D.; Castro, G.R. Hybrid bacterial cellulose-pectin films for delivery of bioactive molecules. New J. Chem. 2018, 42, 7457-7467. [CrossRef]

117. Bodhibukkana, C.; Srichana, T.; Kaewnopparat, S.; Tangthong, N.; Bouking, P.; Martin, G.P.; Suedee, R. Composite membrane of bacterially-derived cellulose and molecularly imprinted polymer for use as a transdermal enantioselective controlled-release system of racemic propranolol. J. Control. Release 2006, 113, 43-56. [CrossRef]

118. Chen, C.; Chen, X.; Zhang, H.; Zhang, Q.; Wang, L.; Li, C.; Dai, B.; Yang, J.; Liu, J.; Sun, D. Electricallyresponsive core-shell hybrid microfibers for controlled drug release and cell culture. Acta Biomater. 2017, 55, 434-442. [CrossRef] [PubMed]

119. Rauchfuß, F.; Helble, J.; Bruns, J.; Dirsch, O.; Dahmen, U.; Ardelt, M.; Settmacher, U.; Scheuerlein, H. Biocellulose for incisional hernia repair-an experimental pilot study. Nanomaterials 2019, 9, 236. [CrossRef] [PubMed] 
120. Piasecka-Zelga, J.; Zelga, P.; Szulc, J.; Wietecha, J.; Ciechańska, D. An in vivo biocompatibility study of surgical meshes made from bacterial cellulose modified with chitosan. Int. J. Biol. Macromol. 2018, 116, 1119-1127. [CrossRef] [PubMed]

121. Wang, B.; Li, P.; Shangguan, L.; Ma, J.; Mao, K.; Zhang, Q.; Wang, Y.; Liu, Z.; Mao, K. A novel bacterial cellulose membrane immobilized with human umbilical cord mesenchymal stem cells-derived exosome prevents epidural fibrosis. Int. J. Nanomedicine 2018, 13, 5257-5273. [CrossRef] [PubMed]

122. Jia, H.; Jia, Y.; Wang, J.; Hu, Y.; Zhang, Y.; Jia, S. Potentiality of bacterial cellulose as the scaffold of tissue engineering of cornea. In Proceedings of the 2009 2nd International Conference on Biomedical Engineering and Informatics, BMEI 2009, Tianjin, China, 17-19 October 2009.

123. Picheth, G.F.; Pirich, C.L.; Sierakowski, M.R.; Woehl, M.A.; Sakakibara, C.N.; de Souza, C.F.; Martin, A.A.; da Silva, R.; de Freitas, R.A. Bacterial cellulose in biomedical applications: A review. Int. J. Biol. Macromol. 2017, 104, 97-106. [CrossRef] [PubMed]

124. Zhang, C.; Cao, J.; Zhao, S.; Luo, H.; Yang, Z.; Gama, M.; Zhang, Q.; Su, D.; Wan, Y. Biocompatibility evaluation of bacterial cellulose as a scaffold material for tissue-engineered corneal stroma. Cellulose 2020, 27, 2775-2784. [CrossRef]

125. Klemm, D.; Schumann, D.; Udhardt, U.; Marsch, S. Bacterial synthesized cellulose-Artificial blood vessels for microsurgery. Prog. Polym. Sci. 2001, 26, 1561-1603. [CrossRef]

126. Tang, J.; Bao, L.; Li, X.; Chen, L.; Hong, F.F. Potential of PVA-doped bacterial nano-cellulose tubular composites for artificial blood vessels. J. Mater. Chem. B 2015, 3, 8537-8547. [CrossRef]

127. Leitão, A.F.; Gupta, S.; Silva, J.P.; Reviakine, I.; Gama, M. Hemocompatibility study of a bacterial cellulose/polyvinyl alcohol nanocomposite. Colloids Surf. B Biointerfaces 2013, 111, 493-502. [CrossRef]

128. Wang, J.; Wan, Y.; Huang, Y. Immobilisation of heparin on bacterial cellulose-chitosan nano-fibres surfaces via the cross-linking technique. IET Nanobiotechnology 2012, 6, 52. [CrossRef]

129. Derikvand, F.; Yin, D.L.T.; Barrett, R.; Brumer, H. Cellulose-Based Biosensors for Esterase Detection. Anal. Chem. 2016, 88, 2989-2993. [CrossRef] [PubMed]

130. Lv, P.; Zhou, H.; Mensah, A.; Feng, Q.; Wang, D.; Hu, X.; Cai, Y.; Amerigo Lucia, L.; Li, D.; Wei, Q. A highly flexible self-powered biosensor for glucose detection by epitaxial deposition of gold nanoparticles on conductive bacterial cellulose. Chem. Eng. J. 2018, 351, 177-188. [CrossRef]

131. Yao, J.; Ji, P.; Wang, B.; Wang, H.; Chen, S. Color-tunable luminescent macrofibers based on CdTe QDs-loaded bacterial cellulose nanofibers for $\mathrm{pH}$ and glucose sensing. Sens. Actuator B Chem. 2018, 254, 110-119. [CrossRef]

132. Allain, J.P.; Echeverry-Rendón, M. Surface treatment of metallic biomaterials in contact with blood to enhance hemocompatibility. In Hemocompatibility of Biomaterials for Clinical Applications: Blood-Biomaterials Interactions; Elsevier Inc.: Oxford, UK, 2018; pp. 279-326. ISBN 9780081004999.

133. Shi, Z.; Li, Y.; Chen, X.; Han, H.; Yang, G. Double network bacterial cellulose hydrogel to build a biology-device interface. Nanoscale 2014, 6, 970-977. [CrossRef] [PubMed]

134. Fang, Q.; Zhou, X.; Deng, W.; Zheng, Z.; Liu, Z. Freestanding bacterial cellulose-graphene oxide composite membranes with high mechanical strength for selective ion permeation. Sci. Rep. 2016, 6, 1-11. [CrossRef]

135. Alonso, E.; Faria, M.; Mohammadkazemi, F.; Resnik, M.; Ferreira, A.; Cordeiro, N. Conductive bacterial cellulose-polyaniline blends: Influence of the matrix and synthesis conditions. Carbohydr. Polym. 2018, 183, 254-262. [CrossRef]

136. Chu, M.; Gao, H.; Liu, S.; Wang, L.; Jia, Y.; Gao, M.; Wan, M.; Xu, C.; Ren, L. Functionalization of composite bacterial cellulose with C60 nanoparticles for wound dressing and cancer therapy. RSC Adv. 2018, 8, 18197-18203. [CrossRef]

(C) 2020 by the author. Licensee MDPI, Basel, Switzerland. This article is an open access article distributed under the terms and conditions of the Creative Commons Attribution (CC BY) license (http://creativecommons.org/licenses/by/4.0/). 